\title{
Virtual Velocity Approach for Estimating Bed Material Transport in Gravel-Bed Rivers: Key Factors and Significance
}

\author{
A. Brenna ${ }^{1}$, N. Surian ${ }^{1}$, and L. Mao ${ }^{2,3}$ \\ ${ }^{1}$ Department of Geosciences, University of Padova, Padova, Italy. \\ ${ }^{2}$ School of Geography, University of Lincoln, Lincoln, UK. \\ ${ }^{3}$ Centro de Investigación para la Gestión Integrada de Desastres Naturales (CIGIDEN), and \\ Instituto de Geografia, Pontificia Universidad Católica de Chile, Santiago, Chile.
}

Corresponding author: Andrea Brenna (andrea.brenna@ phd.unipd.it)

Key Points:

- The virtual velocity approach could represent a viable alternative method to address the bed material load estimation issue in large gravel-bed rivers

- Identification of appropriate spatial scales and use of multiple tracer types represent two crucial methodological improvements

- Seven data input configurations provide different transport estimates and insights about the sensitivity of the approach to different factors.

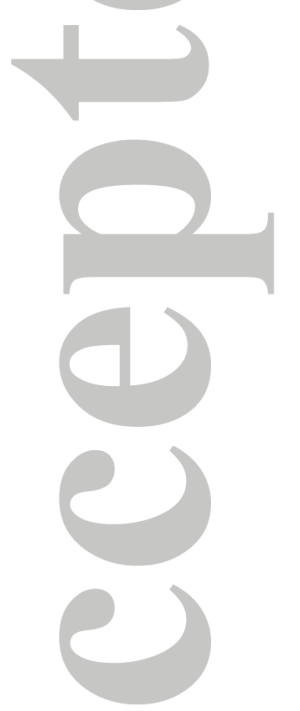

This article has been accepted for publication and undergone full peer review but has not been through the copyediting, typesetting, pagination and proofreading process which may lead to differences between this version and the Version of Record. Please cite this article as doi: 10.1029/2018WR023556 


\section{Abstract}

In large gravel-bed rivers bed material transport estimation is challenging since theoreticallybased formulas often fail to accurately predict sediment fluxes, and it is difficult to carry out field measurements. A viable alternative to direct measurement is provided by the virtual velocity approach representing a hybrid solution to calculate the bed material transport based on a theoretical framework and use of tracers. This work aims to improve the methodology and to assess the role of input factors through a case-study application carried out in the Parma River (Italy). Two tracer types and scour chains were deployed at four sections. Data on water level, transport processes, particle travel distances and active layers were collected over 17 months and 6 events. The transport that occurred during two events was calculated applying different configurations taking in account for several input factors (i.e. grain size, water stage, topography). Applying simple or more complex configurations led to significant differences in transport estimates: in relation to channel morphodynamics, different factors (e.g. variability of water level within the cross-section in multi-thread channels) play a keyrole on transport processes. Results indicate that it is crucial to collect and process field data developing reach-specific transport rating-curves and to combine different type of tracers for monitoring the clast displacement lengths. Based on the methodological improvements and sensitivity analysis addressed in this study, we developed a decision tree in order to design future applications of the virtual velocity approach for estimating the bed material load in different gravel-bed river contexts. 


\section{Introduction}

In gravel-bed alluvial rivers, episodic bed material transport is the most significant factor controlling a river evolution and morphodynamic processes (Ashmore, 2013; Church, 2006; Church \& Ferguson, 2015; Ferguson, 2007). A reliable estimation of bed material transport is a key issue to address several questions (e.g. river morphodynamics study and flood risk management) but it is notoriously hard to achieve (Ferguson, 2007; Haschenburger, 2013).

One of the most used solutions to address this issue is through theoretically-based formulas (e.g. Recking et al., 2012) but often the application of different relations proposed for a given context provides strongly incongruent estimates (Gomez \& Church, 1989; López et al., 2014; Martin \& Ham, 2005). To overcome this issue, traps and portable samplers (Bunte et al., 2004, 2007; Helley \& Smith, 1971) and indirect passive acoustic methods, like geophones, hydrophones (Rickenmann, 2017) and Acoustic Doppler profiling (Rennie et al., 2004a), have been successfully applied in different contexts (Rennie et al., 2004b, 2017; Rickenmann et al., 2014; Wyss et al., 2016). For defining the instantaneous flux, field measurements need to be carried out during transporting events, implying several issues in term of human safety and instrument installation during a flood in the context of wide rivers. Furthermore results are affected by several sources of uncertainty (Bunte et al., 2008; Vericat et al., 2006) due to the high sediment transport spatial (Clayton \& Pitlick, 2007; Ryan \& Dixon, 2007; Williams et al., 2015) and temporal (Hoey, 1992) variability in large rivers. For those reasons, field measurement techniques are more suitable for transport quantification in small streams and the most appropriate methods depend on the specific time-scale of interest.

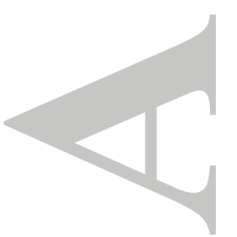


A robust alternative for estimating event-scale bed material rate in large rivers is represented by the morphological approach (Ashmore \& Church, 1998; Lane et al., 1995) which provides reasonable estimates integrated in time and space taking in account for errors (Brasington et al., 2003; McLean \& Church, 1999; Wheaton et al., 2010) based on volumetric differencing techniques. Some improvements have been achieved in the challenge of making the method independent from specific boundary conditions, using surrogate estimates of particle path lengths (Kasprak et al., 2015; Pyrce \& Ashmore, 2003a; Vericat et al., 2017) based on local morpho-types (e.g. dominant particles travel distances tie to the length scale of the bar) or employing tracer-particle travel distances (e.g. Papangelakis \& Hassan, 2016; Pyrce \& Ashmore, 2003b). However, the specification of transport rate from volumetric change $(\Delta V)$ using the diffuse sediment budgeting approach $\left(\Delta V=Q_{b_{\text {in }}}-Q_{b_{\text {out }}}\right)$ requires knowledge of a reference river section where the transport is known (Merz et al., 2006; Surian \& Cisotto, 2007 ) in order to reduce the equation unknowns from two (reach transport in- $\left(Q_{b_{i n}}\right)$ and out$\left.\left(Q_{b_{\text {out }}}\right)\right)$ to one.

Passive tracer-clasts (see Hassan \& Roy, 2016) have been extensively used for sediment dynamics monitoring in several field studies (e.g. Bradley \& Tucker, 2012; Church \& Hassan, 1992; Haschenburger, 2013b; Hassan \& Bradley, 2017; Petit, 1987; Sear, 1996; Thompson \& Wohl, 2009). One of the most promising application concerning tracer-data is the development of calculation procedures to estimate bed material transport involving particle displacement lengths. An important parameter obtainable from tracers is the virtual velocity of the entrained grains, defined as the mean velocity characterizing the clasts during the period for which particles might be in motion (i.e. considering travel distances and competence period as in Ferguson and Wathen (1998) and Liébault et al. (2012)). Virtual 
velocity is different from the actual instantaneous-velocity since, also during a "competent period", the coarse grains are characterized by short periods of quick movement interspersed with intervals of rest (Haschenburger \& Church, 1998). Field measurements of virtual velocity have been used to estimate bed material transport in small streams (e.g. Haschenburger \& Church, 1998; Liébault \& Laronne, 2008) assuming uniform sediment transport for the whole section. In large gravel-bed rivers the active sediment transport mechanisms can change in time, at different river sections but also considering different locations at the same section, due to the relation between topography, water flux and local sediment characteristics (Haschenburger \& Wilcock, 2003; Surian et al., 2009). Wilcock (1997) developed a useful theoretical framework that, taking in account these aspects and considering the local shear stress induced by the water flow on the channel-bed, seems appropriate to address the transport estimate at the "competent-event" time scale in wide rivers. Since Wilcock's framework (1997) has been applied in only few cases (e.g. Mao et al., 2017), several methodological issues have not yet been addressed.

This work applies the virtual velocity framework proposed by Wilcock (1997) through a tracer-based approach to estimate bed material transport in large gravel-bed rivers. We collected data through a two-year monitoring program in a sector of a north-Apennine river using different types of tracers. The research aims to assess the approach, in particular evaluating for the first time the significance of each factor that feeds into the calculation through a simplified sensitivity analysis. The specific research objectives are (i) to define a spatial scale (e.g. segment, reach, sub-reach) for field data collection and processing appropriate for the local river characteristics; (ii) to assess which tracer types are more suitable to provide reliable travel distances and to test the accordance of data collected from 
different tracer types; (iii) to assess how each input factor (e.g. grain size, water stage, section topography) affects transport estimates and if such estimates vary significantly using different input factor configurations.

\section{Materials and Methods}

2.1 Study site and monitored events

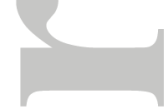

The study was conducted in a gravel- to cobbles-bed sector of the Parma River (Northern Apennines, Italy), which drains a $815 \mathrm{~km}^{2}$ catchment (Figure 1). The upstream boundary of the sector is at the closure-dam of the Marano retention basin, which retains all coarse sediment and so provides a zero-flux boundary condition. As a result, the channel pattern changes notably upstream and downstream from the dam, being respectively braided (average width $=340 \mathrm{~m}$; braiding index $=3$ ) and single-thread with alternate bars or wandering (average width $=60-160 \mathrm{~m}$; braiding index $=1.2$ ). Along the $4 \mathrm{~km}$-long study sector, we selected four monitoring cross-sections: sections 1 and 2 (slope $=0.0051$; width $=90-110 \mathrm{~m}$ ), located respectively $1950 \mathrm{~m}$ and $2200 \mathrm{~m}$ downstream from Marano dam, and sections 3 and 4 (slope $=0.0051 ;$ width $=120-140 \mathrm{~m}$ ), located respectively $3250 \mathrm{~m}$ and $3400 \mathrm{~m}$ downstream from the dam (Figure 1). The study sector features (width, sediments characteristics, morphology) vary downstream from the dam, making possible to recognize two different reaches (Figure 1) characterized by internal variability at the geomorphic unit scale.

The hydrological regime is seasonal with most precipitation occurring between November and April (Figure 2a). The mean annual flow is $11 \mathrm{~m}^{3} \mathrm{~s}^{-1}$. Not knowing a priori the water 
discharge required to induce a competent bed material transporting event at the considered sections, we calibrated the monitoring implementation based on the fieldwork experience. The first field-observations (e.g. observations of morphological changes or sediment mobilization) allowed us to define a discharge threshold approximately equal to $35 \mathrm{~m}^{3} \mathrm{~s}^{-1}$ to identify a monitoring-significant (i.e. transporting) event. Over the 17 months of monitoring (January 2016 - May 2017), nine events occurred, the largest one with a recurrence interval of 2.1 years (peak discharge $=227 \mathrm{~m}^{3} \mathrm{~s}^{-1}$, Figure $2 \mathrm{~b}$ ). Pre-event installation and field monitoring, each one covering a single flood, were carried out only for six events, due to logistical issues.

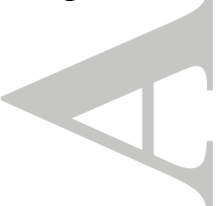

2.2 Estimating bed material transport through the virtual velocity approach

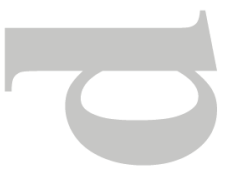

Wilcock's (1997) approach calculates the mass and size distribution of material entrained and transported by flow from a unit channel area during a defined period. Three mobility conditions are identified: no motion, partial mobility and full mobility. Partial mobility is the condition in which only a fraction of the surface particles of a certain grain size are mobilized over a time interval (Wilcock \& McArdell, 1997). The mass of material of the $i$-size entrained from a defined surface area, $M_{i}\left(\mathrm{~kg} \mathrm{~m}^{-2}\right)$ is given by:

$$
M_{i}^{P T}=\frac{m_{i} F_{i} Y_{i}}{D_{i}^{2}}
$$

where $m_{i}$ is the mass of a single particle of size $i(\mathrm{~kg}), F_{i}$ is the proportion of fraction $i$ in the surface grain distribution, $D_{i}$ is the diameter of fraction $i$ grains $(\mathrm{m})$ and $Y_{i}$ is the proportion of surface particles of the fraction $i$ transported in the event. The mass of a single grain of fraction $i$ is calculated using the spherical approximation $m_{i}=\left((\pi / 6) \rho_{s} D_{i}{ }^{3}\right)$ where $\rho_{s}$ is the 
density of the grain material $\left(\mathrm{kg} \mathrm{m}^{-3}\right)$. When the tractive forces overcome a certain threshold such that $Y_{i}$ becomes 1 , full mobility occurs. In this case, all surface particles of a certain size are removed (Wilcock \& McArdell, 1997) and subsurface grains could be transported up to the thickness of the active layer (Wilcock, 1997). Equation (1) becomes:

$$
M_{i}^{F T}=\frac{m_{i} F_{i} d_{s}}{D_{i}^{3}}
$$

where $d_{s}$ is the active layer thickness (m) and $F_{i}$ is now referring to the active layer.

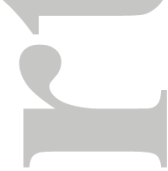

When $M_{i}$ is known, to obtain the unit mass fractional transport rate $\left(q_{i}^{u}, \mathrm{~kg} \mathrm{~m}^{-1} \mathrm{~s}^{-1}\right)$ it is necessary to multiply the mass of entrained sediment $\left(M_{i}, \mathrm{~kg} \mathrm{~m}^{-2}\right)$ by the virtual velocity characterizing the $i$-size particles movement $\left(V_{i}, \mathrm{~m} \mathrm{~h}^{-1}\right)$ :

$$
q_{i}^{u}=M_{i} V_{i}
$$

The main opportunity provided by this framework is to allow the calculation of $q_{i}{ }^{u}$, referring to a definable portion of channel.

Mobility conditions are determined by the intensity of the tractive forces locally induced by the flow on the streambed, expressed by the shear stress $\left(\tau, \mathrm{N} \mathrm{m}^{-2}\right)$. We used the depth-slope approach (Mueller et al., 2005; Wilcock, 1993) $\tau=\rho_{w} g h_{w} S$ where $\rho_{w}$ is the water density (kg $\left.\mathrm{m}^{-3}\right), g$ is the gravity acceleration $\left(\mathrm{m} \mathrm{s}^{-2}\right), h_{w}$ is the water depth $(\mathrm{m}$, defined for each $1-\mathrm{m}$ wide portion of cross-section), and $S$ is the streambed slope (in our case, it was averaged considering $400 \mathrm{~m}$ centered on each section to represent the mean slope of the entire section). To make $\tau$ independent from the sediment grain size, we used the conventional dimensionless 
formulation of shear stress $\left(\tau^{*}\right)$ considering the local median grain size $\left(D_{50}\right)$ applying equation (4):

$$
\tau^{*}=\frac{\tau}{\left(\rho_{s}-\rho_{w}\right) g D_{50}}
$$

assuming a $\rho_{s}=2600 \mathrm{~kg} \mathrm{~m}^{-3}$ and using the surface $D_{50}$ as in Mueller et al. (2005) and Parker

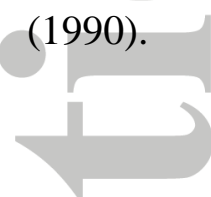

As proposed by Mao et al. (2017), we simplified equation (1) as follows:

$$
M_{i}^{P T}=\frac{m_{i} F_{i} Y}{D_{i}^{2}}
$$

where $Y$ is the proportion of mobilized streambed for a defined bed area and it is a proxy of the partial transport intensity defined like a condition of sediment mobility in which some surface grains remain immobile over the duration of a transport event, indicating the active portion of all grains on the bed surface (Haschenburger \& Wilcock, 2003). Through equations (2), (3) and (5) we calculated values referred to a single $i$ grain size fraction. To obtain the whole entrained material as a function of $\tau^{*}$, it is required to calculate the mass of entrained sediment and the fractional mass transport rate for each grain size class and then to sum all fractional results:

$$
q^{u}=\sum q_{i}^{u}
$$

where $q^{u}$ is the total unit mass transport rate $\left(\mathrm{kg} \mathrm{m}^{-1} \mathrm{~s}^{-1}\right)$ for the transported sediment. 
2.3 Field monitoring procedures and data processing

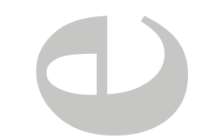

2.3.1 Topographic surveys, bed material grain size and tracers

The four cross-sections were surveyed before and after each monitored event (Figure $2 b$ ) using a differential global positioning system (dGPS, Leica GS14, vertical accuracy \pm 0.02 m). Employing aerial-photographs, sediments-vegetation field observations and elevation data, and using criteria reported in Mao and Surian (2010) geomorphic units (Belletti et al., 2017; Brierley \& Fryirs, 2013; Wheaton et al., 2015) recognizable along the sections were classified in: main channel, secondary channels, low and high bars, islands, floodplains and terraces (Figure 3). For each pre-event installation (Figure 2b), we selected between two and eight sites along each section (Figure 3) representative of each geomorphic unit surfacesediments suitable for image grain size analysis and tracer installation (e.g. lack of fine sediments and herbaceous vegetation). Using an aluminum frame, we defined rectangular areas of $0.8 \mathrm{~m} * 0.6 \mathrm{~m}$ (respectively cross-stream and downstream) which were orthogonally photographed using a 16 megapixel digital camera. The photos were processed by the Digital Gravelometer software (Graham et al., 2005a, 2005b, 2010) deriving the surface grain-size distribution characterizing each site. Due to the camera resolution, we applied a lower truncation of $6 \mathrm{~mm}$, comparable with that commonly used in the manual pebble count (Bunte \& Abt, 2001; Wolman, 1954). Using the same procedure, we acquired and analyzed six photographs of vertical exposures visible in incised bar margins along the study sector (Figure 3), deriving values about the subsurface grain-size distribution (Storz-Peretz \& Laronne, 2013). Fine material $(<6 \mathrm{~mm})$ in average accounts for about $20 \%$ of sediment volume in the study reach for both surface and subsurface sediment. Field observations about 
the streambed material fabric and structuring were carried out focusing on evidence of armoring (e.g. imbrication and grain sorting).

After the photographing, the surface of the patches $(0.8 \mathrm{~m} * 0.6 \mathrm{~m})$ was painted using spray paint, i.e. each clast in the surface became a painted tracer (overall, 117 painted areas and about 38,000 painted clasts coarser than $6 \mathrm{~mm}$ were colored). This procedure avoids modifying the natural surface-sediment structure, and easily marks a large number of clasts without grain size limitations. The elevation (m a.s.l.) of each installed painted area were determined using the dGPS. To maximize the recovery rate we coupled painted areas with Passive Integrated Transponders tags (23-mm long PITs, Texas Instruments, LF Glass Transponder) inserted inside drilled individual-clast and detectable using an antenna if buried up to $0.3-0.4 \mathrm{~m}$. For each pre-flood installation, we seeded between six and ten PITs for each painted area (898 PITs were employed during the monitoring with, on average, 150 PITs seeded during each event, similar to Chapuis et al., 2015), choosing clasts with sizes comparable with the coarser component of the local bed material (ranging from 28 to 180 $\left.\mathrm{mm} ; D_{50_{P I T S}}=76 \mathrm{~mm}\right)$. PIT tagged clasts were placed close to the painted areas replacing existing clasts with similar size and shape, avoiding protrusion from the bed, in order to mimic the interlocking of natural surface particles (Chapuis et al., 2015).

2.3.2 Section-specific water flow

Information about water level are required to calculate tractive forces (equation 4). To obtain section-specific hydrographs we used two techniques: local pressure transducers and field 
evidence. One pressure hydrometer (Solinst Levelogger 3001, accuracy $\pm 0.005 \mathrm{~m}$ ) was installed in the main channel at each study section (Figure 3), anchoring them at stable supports in hollow metal casings (Figure 3e). Knowing the pressure transducers elevation, the water level above it and using a barometric compensation (atmospheric data collected by a Solinst Barologger 3001 installed near to the study sector) it was possible to obtain a hydrograph referred to the specific river location with a precision of $\pm 0.02 \mathrm{~m}$ and temporal resolution of 30 minutes. Field evidence of the maximum level reached by water during a flood (i.e. trash lines) in different portions of the channel (main channel and secondary channel banks or bar surfaces) has been collected using a dGPS after each monitored event at each section. Finally, data from local hydrometers and field evidence have been related with the corresponding discharges provided by the Marano dam gauging station (time resolution of 30 minutes) through simple regression analysis (i.e. polynomial relationships).

\subsubsection{Sediment mobility}

The sections were surveyed immediately after the transport events. The painted areas were orthogonally photographed again and using the approach applied by Mao and Surian (2010) we described the effects of the transport. Areas could be: located above the maximum water stage (AWS), under no-motion (NM), partial transport (PT) (when some surface grains entrained and others remained immobile, independently of their size considering the bed as a whole, as defined by Haschenburger and Wilcock, 2003) or full transport (FT) conditions (referred to painted areas interested by a complete particle removal). After each monitored event, we searched and collected all the tracer grains that moved downstream from the activated study sites. For the painted particles the survey was limited to the visible grains on 
the bed surface whereas, using an antenna, it was possible to recover also buried PITs (collected and stored for the following installations). Particle size (b-axes) and travelled distance from the center of the origin study site of each recovered tracer-grain were individually measured using a caliber and a tape, respectively.

2.3.4 Proportion of the bed mobilized and Active layer

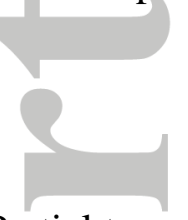

Partial transport processes reflect on equation (5) through the $Y$ parameter which refers to the proportion of mobilized bed material for a defined area, varying from 0 (no motion) to 1 (full transport). To quantify the extent of partial transport over the study sites we used the photographs collected after the events analyzing them as described by Mao et al. (2017). The painted residue pixels represent the proportion of not mobilized streambed surface, and $Y$ (a proxy for the extent of partial transport at the painted area scale) is equal to one minus that value. value. (1)

Where locally full mobility occurs, the subsurface sediment can be mobilized due to the establishment of a mobile surface layer (considered in equation (2)). To collect field evidence about active layer thickness (erosion and sedimentation) we used scour chains and topographic surveys. Scour chains record the event-based maximum depth of scour or deposition (event active layer, as defined by Church and Haschenburger, 2017), taking in account also two-phases processes (Carling, 1987; Houbrechts et al., 2012). Following the approach used by Laronne et al. (1994), for four of the monitored-events, we installed from one to three chains at each section in correspondence of some selected painted areas, using 
during the entire study period 28 chains in correspondence of painted sites (12 at sections 1-2 and 16 at sections 3-4) (Figure 3). To extend the active layer dataset, we also employed topographical data measuring the post-event bed elevation in correspondence of each painted area where transport occurred, determining the variation in comparison with the pre-event elevation. Painted area elevation changes can just provide the sum of scour and fill at the considered point (i.e. punctual net variation), possibly leading to underestimation of the actual event active layer thickness in case of two-phases erosion-deposition processes, when compensation can occur (Lindsay \& Ashmore, 2002).

2.3.5 Sediment transport calculation

Considering section topographies, event hydrographs and the local bed-material $D_{50}$ (in function of geomorphic unit distribution characterizing the sections during the event), we calculated the $\tau^{*}$ (equation (4)) active on the river bed for each $1 \mathrm{~m}$-wide portion of crosssections (local $\tau^{*}$ ) with a time interval of 30 minutes (instantaneous $\tau^{*}$ ). Monitored parameters (mobility conditions, $Y$ and $d_{s}$ ) collected from all flooded painted areas were coupled with the maximum dimensionless shear stress $\left(\tau^{*} \max \right)$ active at the event peak on the specific study site, since collected data are considered as the results of the maximum acting tractive forces. The grain size specific virtual velocity ( $V_{i}$, as defined by Wilcock, 1997) was calculated dividing the mean $i$-size fraction travel distance by the duration of transport determined considering the period for which the $\tau^{*}$ locally active on the streambed was adequate to induce particle movement. Through regression analysis between the field monitored $\left(Y\right.$ and $\left.d_{s}\right)$ or computed (mobility conditions, $\left.V_{i}\right)$ parameters and the $\tau^{*}{ }_{\max }$, we defined empirical relations able to determine the parameters values in function of local and 
instantaneous $\tau^{*}$ active on the streambed. These relations $\left(d_{s}=\mathrm{f}\left(\tau^{*}\right)\right.$ and $\left.Y=\mathrm{f}\left(\tau^{*}\right)\right)$ allowed to deal with the fractional transport equations (Equations (2) and (5)) and to calculate the unit fractional sediment transport rate $\left(q_{i}^{u}\right.$, Equation (3)) introducing the virtual velocity empirical relations $V_{i}=\mathrm{f}\left(\tau^{*}, D_{i}\right)$. Considering the local sediment grain size distribution, the total unit mass transport rate $\left(q^{u}\right)$ was calculated using equation (6) on each $1 \mathrm{~m}$-wide portion of the sections with a temporal resolution of 30 minutes. Integrating the single calculated total unit mass transport rates over space (the cross-section extension) and time (the duration of the transport event), we estimated the bed material transport occurring for a specific section during a single transport event.

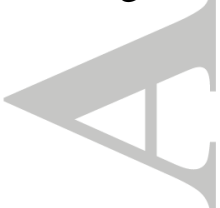

2.3.6 Calculation factors and sensitivity analysis

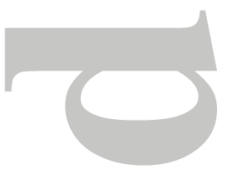

We calculated the bed material load for all channel material consisting of clasts larger than 6 $\mathrm{mm}$ (b-axes). To apply the described calculation procedure it is necessary to consider some factors influencing the data input choices and possibly leading to relevant differences in the estimates. Using the obtained empirical relations and the associated uncertainties, we tested the method sensitivity considering four application factors, selected on the base of their hypothesized importance and the efforts required to measure such factors during the fieldwork. Calculations were carried out through seven data input configurations (Table 1) designed in order to evaluate the impact of single selected factors and the effects of some of their possible combinations. The simplest setting (configuration 1) considers a single section $D_{50}$ for $\tau^{*}$ calculation and an average water stage for the whole section, fixed cross-section topography during a transport event (i.e. the pre-event topography) and a single sectionsediment grain size distribution for the fractional transport calculation. We progressively 
introduced application factors taking into account some aspects related to the natural complexity of the system: using (i) spatial variable water level along a single section (configuration 2) we tested the importance of the water flux at specific channel locations; considering (ii) local streambed $D_{50}$ (configuration 3 ) and (iii) geomorpho-unit specific grainsize curves (configuration 6) we evaluated the impact of the sediment characteristics on the tractive forces effectiveness and the importance of the fractional calculation; employing (iv) variable section topographies (i.e. pre-event topography which progressively changes into post-event topography during a single event calculation when full transport occurs) (configuration 4), we looked for the effect of the morphology evolution during a competent event. Configurations 5, 6 and 7 (the latter one taking into account all considered factors), allowed us to obtain new insights about the combined effects of different factors on the sediment flux estimates. The significance of the differences in estimates provided by different factors configurations have been evaluated considering the calculation uncertainties also in relation with the natural variability of sediment flux intensity at a given flow in a given section (Ashmore, 2013).

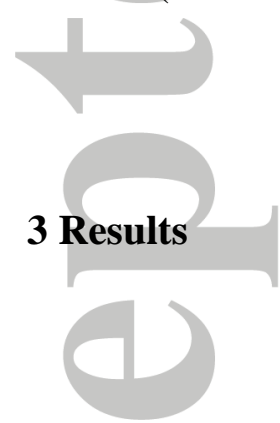

3.1 Field observations

3.1.1 Grain size and bed armoring

Overall, 105 surface bed sediment and 6 vertical incised-bar margins (Figure 3) photographs (each photograph contains from 100 to 500 grains coarser than $6 \mathrm{~mm}$ ) were collected. 
Obtained grain size curves, divided in 11 half-psi classes (i.e. $p s i=-p h i=\log _{2} D ; D=$ grain size, mm), show a broad variability. Mean $D_{50}$ and $D_{84}$ were derived accordingly to different groupings: finally 6 different mean curves (Figure 4a) and characteristic parameters (Figure 4b) were considered in order to describe the average surface grain size distribution according to section location (i.e. sections 1-2 and 3-4) and geomorphic unit (main channel, secondary channel and bar). Those curves show a decreasing trend in the grain size from upstream to downstream sections with main channel characterized by coarser material and secondary channels by finer material (Figure 4b). No temporal trends in grain sizes have been identified during the data-collecting period. Similar subsurface grain-size distributions along the entire study sector were obtained from the vertical photographs analysis, determining mean $D_{50}$ equal to $36 \mathrm{~mm}$ (Figure 4b). Field observations allowed us to recognize surficial grain sorting, imbrication and presence of coarser surficial grains in the upstream sections: this evidence of streambed armoring tend to decrease moving downstream from the dam. The calculated armor ratios $\left(\boldsymbol{D}_{\mathbf{5 0}_{\text {surf }}} / \boldsymbol{D}_{\mathbf{5 0} \text { subsurf }}\right)$ confirm field evidence: armor ratio ranges from 1.56 to 2.86 (mean 1.75) in sections 1 and 2, whereas it ranges from 1.20 to 2.46 (mean 1.47) in sections 3 and 4. In accordance with Hassan et al. (2006), values higher and lower than 1.50 have been respectively considered as indicative of high and moderate bed armoring for intermittent rivers.

\subsubsection{Water depth and flow intensity}

Data collected by hydrometers referred only to the main channel. Downstream sections are characterized by wandering morphology: the maximum water levels reached in the secondary channel for section 3 determined by the trash-line measures show that water level is not uniform within the section at a given water discharge, being lower in the secondary channel 
during all the monitored events (Figure 5). We derived location-specific empirical relationships between local water-stages evidence (i.e. hydrometers data and maximum levels obtained by trash-lines) and corresponding discharge data at Marano dam through simple regression analysis (Figure 5). Based on local water levels (time resolution $=30$ minutes) and grain size distribution, the local-instantaneous $\tau^{*}$ (equation (4)) shows a broad variability, being higher at locations were sediments are finer and lower were bed material is coarser (Figure 6a, b, c).

3.1.3 Assessment of the proportion of the bed entrained

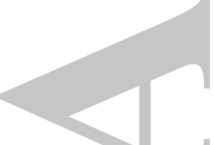

Considering the data derived from the painted areas under partial transport conditions, we related through simple regressions the calculated fraction of mobilized streambed material $(Y)$ with the $\tau^{*}{ }_{\max }$ experienced by the study site during the event. $Y$ tends to increase with the tractive forces active on the bed. Separately considering data collected from sections 1-2 and 3-4, the best-fit regressions, characterized by different trends (Figure 7a), give logarithmic equations:

$$
\begin{array}{ll}
Y^{1-2}=4.10+1.04 \log \left(\tau^{*}\right) & \left(\mathrm{R}^{2}=0.93, \mathrm{SE}=0.08\right) \\
Y^{3-4}=4.16+0.97 \log \left(\tau^{*}\right) & \left(\mathrm{R}^{2}=0.82, \mathrm{SE}=0.11\right)
\end{array}
$$

Equations (7) and (8), respectively referring to upstream and downstream sections, have been employed to calculate the local and instantaneous proportion of activated streambed at section locations experiencing partial transport (Figure 6d). The standard error of regressions (SE) has been statistically derived as a good approximation of the $95 \%$ prediction intervals.

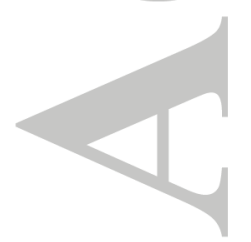


3.1.4 Estimate of the active layer thickness

We related through simple regressions the maximum measurable erosion or deposition thickness (also in case of two-phase process) with the $\tau^{*}{ }_{\text {max }}$. Only 4 out of 28 installed eventscour chains provided reliable estimate of the active layer thickness due to some technical issues (e.g. complete chain removal caused by lateral erosion or tear). Plotting chains data with those collected by topographic surveys ( 27 measurements) it turned out that the two techniques provided comparable results (Figure 7b). For this reason, we decided to fit jointly chains and elevation changes data, elaborating separately data collected from sections 1-2 and 3-4. The best-fit regressions follow the squared-x models:

$$
\begin{array}{ll}
d_{s}{ }^{1-2}=-0.021+40.3\left(\tau^{*}\right)^{2} & \left(\mathrm{R}^{2}=0.74, \mathrm{SE}=0.09 \mathrm{~m}\right) \\
d_{s}^{3-4}=0.011+35.7\left(\tau^{*}\right)^{2} & \left(\mathrm{R}^{2}=0.83, \mathrm{SE}=0.06 \mathrm{~m}\right)
\end{array}
$$

Equation (9) and equation (10), respectively referring to upstream and downstream sections, have been employed to calculate the local and instantaneous mobile surface layer thickness (Church \& Haschenburger, 2017) at section locations experiencing full transport (Figure 6e).

\subsubsection{Estimate of travel distances}

Our travel distance data refer to "unconstrained-stone conditions" since we considered the first displacements after tracer seeding for both employed tracers types which start from the bed surface. Mobilized painted clasts ranged from 2 to $170 \mathrm{~mm}$ in size (but we considered only particles coarser than $6 \mathrm{~mm}$ ), while those with PITs ranged from 28 to $165 \mathrm{~mm}$. We analyzed the collected data in terms of travelled distances, grain size, $\tau^{*}{ }_{\max }$ active on the source study site and tracer type (Figure 8$)$. For low to medium $\tau^{*}{ }_{\max }(<0.04)$, painted particles displacement lengths do not show statistically significant differences with those 
provided by PITs (Figure 8a, b, c). For high $\tau^{*}{ }_{\max }$ values, leading to full transport, the number of collected painted clasts decreases. Where some clasts were found (Figure 8d), PITs based distances seem to be about $35 \%$ higher. For very high values of $\tau^{*}{ }_{\max }$ the collected data came almost exclusively from PITs (Figure 8e, f). The number of tracers collected in relation to moderate transport conditions is around 100-300 clasts for study site predominantly coming from painted clasts, while for high $\tau^{*}$ values the recovered tracers range between 6 and 40 . Overall 4991 moved painted particles were collected. Considering the number of clasts colored at each painted area and the calculated study sites $Y$, we estimated a total value of about 18,000 moved painted particles from the 77 study sites interested by transport (47\% of the colored grains). The average painted clasts recovery rate is about $28 \%$, but, referring to the single study sites, it varies from 0 (intense transport, e.g. Figure 8f) to about $100 \%$ (low transport, e.g. Figure 8a). Overall 467 PIT tagged clasts were entrained (52\% of the seeded PITs) and 401 were recovered both at the surface or buried (71 PITs, at a depth variable between few centimeters and $0.45 \mathrm{~m}$, in agreement with the estimate of the active layer thickness). The PITs recovery rate after a single displacement is close to $100 \%$ for partial transport conditions and commonly more than $80 \%$ for very intense full transport conditions.

\subsection{Computation of parameters}

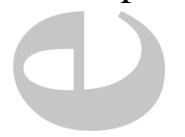

3.2.1 Sediment mobility: defining thresholds between mobility conditions

Considering the 117 installed sites (Figure 3), 15\% of them were at elevations that were not flooded by the monitored events, $19 \%$ experienced no motion conditions, $43 \%$ and $23 \%$ were in partial and full transport conditions, respectively. The collected data were analyzed considering the $\tau^{*}{ }_{\max }$ experienced by a painted area through one-way analysis of variance 
(ANOVA), to define thresholds in terms of $\tau^{*}$ between mobility conditions. As a first step the whole dataset was considered, showing that the three mobility classes were statistically different ( $\mathrm{p}$-value <0.002), but characterized by a significant overlap (Figure 9a). Then, considering two subsets, with data collected respectively at sections 1 and 2 (Figure 9b) and sections 3 and 4 (Figure 9c), we obtained strongly different classes (p-values $<0.001$ in both analyses). As the probability density functions of mobility classes are symmetrical and characterized by the same shape, to define the local thresholds of $\tau^{*}$ able to induce different mobility conditions we used the median value between the $75^{\text {th }}$ percentile of the lower mobility class and the $25^{\text {th }}$ percentile of the upper mobility class distributions. Using the two subsets, local thresholds were defined: full transport occurs at $\tau^{*}$ higher than 0.048 and 0.037 , respectively for upstream and downstream sections; partial transport occurs at $\tau^{*}$ between $0.020\left(\tau_{c}^{*}\right)$ and 0.048 and $0.015\left(\tau_{c}^{*}\right)$ and 0.037 , respectively for 1-2 and 3-4 sections. Local mobility thresholds have been employed to determine the processes active along sections in function of the $\tau^{*}$ (Figure 6c).

\subsubsection{Virtual velocity}

Using the 30 minutes bed-acting $\tau^{*}$ data and the defined mobility-thresholds, we were able to calculate the time of movement for each study site (hours). We used a combination of painted and PIT-tagged clasts displacement-length data to calculate mean travel distances $(\mathrm{m})$ for each of the defined 11 particles size-classes for each site during a competent event. Virtual velocity $\left(\mathrm{m} \mathrm{h}^{-1}\right)$ was derived dividing the mean displacement length by the mobility duration, determined as the total time for which the $\tau^{*}$ active on the study site was larger than that needed to initiate clast movement (i.e. $\tau^{*}>\tau_{\mathrm{c}}^{*}$ ) (local competent flow duration, e.g. as in Haschenburger \& Church, 1998). Considering 77 sites and 11 size-classes, we would 
potentially have had a total of 847 data relating virtual velocity to grain size and $\tau^{*}{ }_{\max }$. Actually, for several size-classes we did not have displacement lengths: we used 268 inputs (127 and 141 respectively from sections 1-2 and 3-4) in order to apply multiple regression analysis between $V_{i}, D_{i}$ and $\tau^{*}{ }_{\max }$ distinguishing upstream and downstream sections data:

$$
\begin{array}{ll}
V_{i}^{1-2}=0.64-15.07 D_{i}+44.98 \tau^{*} & \left(\mathrm{R}^{2}=0.49, \mathrm{SE}=1.27 \mathrm{~m} \mathrm{~h}^{-1}, \mathrm{p} \text {-value }<0.05\right) \\
V_{i}^{3-4}=1.76-16.65 D_{i}+32.23 \tau^{*} & \left(\mathrm{R}^{2}=0.48, \mathrm{SE}=0.78 \mathrm{~m} \mathrm{~h}^{-1}, \mathrm{p} \text {-value }<0.05\right)
\end{array}
$$

Equations (11) and (12), showing that virtual velocity $\left(\mathrm{mh}^{-1}\right)$ has direct and inverse relations with $\tau^{*}$ and grains size $\left(D_{i}\right)$ respectively, have been employed to calculated the specific virtual velocity of each grain-size class moved during a transport event at a specific channel location and time interval.

\subsection{Bed material fluxes}

\subsubsection{Temporal and spatial flux variability}

\section{Considering the empirical relations between $\tau^{*}$ and the parameters, we used Wilcock's} equations (1997) to determine bed material transport rating curves. We applied equation (3) and then, using the six local surface grain size curves (Figure 4a), equation (6) to obtain six rating curves for the three considered geomorphic units (MC, B, SC), in the upstream (1-2) and downstream (3-4) sections (Figure 10). The rating curves $\tau^{*}-q^{u}$ provide an estimation of local unit bed material transport $\left(\mathrm{kg} \mathrm{m}^{-1} \mathrm{~h}^{-1}\right)$ as a function of the local $\tau^{*}$ active on the bed. The six curves start in correspondence of the $\tau^{*}{ }_{c}$ and are characterized by two sub-trends referring to partial transport and, above the PT-FT thresholds, to full transport conditions. Since the measured depth of the mobilized surface layer (Figure 7b) is commonly thinner 
than the observed armored surface depth (about 0.3-0.4 m) and due to the results obtained about the persistence of the armor layer during competent flows (Wilcock \& DeTemple, 2005), we considered the surface grain size distributions also for the elaboration of the full transport range rating-curves. Considering $\tau^{*}$ active on the bed (Figure $6 \mathrm{c}$ ), we determined the instantaneous-section bed material load as the sum of the unit bed material transports (1 m-wide, 30 minutes) along the whole section, using $\tau^{*}-q^{u}$ curves specific for section and geomorphic unit (Figure 6f). The event-section bed material load was determined as the sum of the instantaneous-section bed material loads calculated for the entire duration of the transport event.

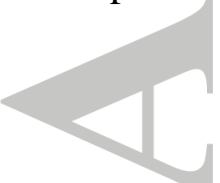

\subsubsection{Uncertainties and natural variability in sediment transport}

Due to several sedimentological (e.g. surface material packing and structure) and morphodynamic (e.g. sediment supply, fluvial-unit dynamics) reasons, local-unit bed material load can be very different responding to a given $\tau^{*}$ (Cudden \& Hoey, 2003). The $\tau^{*}-q^{u}$ curves were developed starting from empirical relations based on field data $\left(Y, d_{s}, V_{i}\right)$ collected from study sites located at different geomorphic units, under different morphodynamic transportconditions and subjected to the natural variability of local sediment mobilization mechanisms which ultimately produced data scattering. For these reasons, empirical equations are coupled with uncertainty bands determined using the standard error of regressions (see Figures $6 \mathrm{~d}, 6 \mathrm{e}$, 7 and 8). Propagating the sources of uncertainty through the rule for multiplied quantities (i.e. adding in quadrature SEs of $Y$ and $V_{i}$ for partial transport and SEs of $d_{s}$ and $V_{i}$ for full transport) for each $\tau^{*}$ value, we determined the variability bands of the $\tau^{*}-q^{u}$ curves (Figure 10). Using the $\tau^{*}-q^{u}$ curves and the variability bands, for each local and instantaneous $\tau^{*}$ value considered in our calculations we determined the mean, the maximum and the 
minimum associated $q^{u}$ (Figure 6f). Integrating those values on the whole section, the corresponding instantaneous-section transport values were determined. The same operation allowed the calculation of the mean, maximum and minimum event-section transport values integrating the instantaneous-section fluxes (mean, maximum and minimum) over the hydrograph trend and finally to determine the variability (i.e. \pm ) associated with each

\section{estimate.}

3.3.3 Transport estimate using different data input configurations

We tested the virtual velocity approach at two morphologically different sections (sections 1 , sinuous with alternate bars, and 3, wandering; see Figure 3) and for two events of different magnitude (May 2016 - RI $<1$ year and November 2016 - RI= 2.1 year; see Figure 2b). All calculations were carried out using rating curves derived for specific locations (i.e. sections 1-2 and 3-4 and relative empirical relations) but they can be applied to a sediment transport calculation according to different input factors configurations. The estimates have been performed considering seven configurations (see tables 1 and 2). Starting from the simplest setting we applied the calculation introducing factors one at time (configurations 2, 3 and 4) and combining them (configurations 5,6 and 7). The first five input settings use only two mean $\tau^{*}-q^{u}$ rating curves derived considering one average grain size distribution curve for sections 1-2 and sections 3-4 (Figure 10c), whereas configurations 6 and 7 consider the six $\tau^{*}-q^{u}$ rating curves derived for specific geomorphic units (Figures 10a and 10b).

Event bed material transport estimates are presented as volume of moved material through a section during a competent flux with an uncertainty determined through the variability estimation procedure applied for each configuration. To convert the original results calculated 
in $\mathrm{kg}$ to sediment volume $\left(\mathrm{m}^{3}\right)$, we considered sediment porosity equal to 0.25 (not defined in the field due to the measure difficulties) as suggested for alluvial gravels by Carling and Reader (1982) and adopted in previous studies carried out for similar material (e.g. Martin \& Church, 1995; Surian \& Cisotto, 2007). At section 1 transport estimates vary from $64 \pm 44 \mathrm{~m}^{3}$ (configuration 1) to $3 \pm 3 \mathrm{~m}^{3}$ (configuration 7) and from $614 \pm 158 \mathrm{~m}^{3}$ (configuration 1) to $158 \pm 74 \mathrm{~m}^{3}$ (configuration 7) respectively for May and November 2016 events (table 2). At section 3, configuration 1 transport estimates $\left(533 \pm 193 \mathrm{~m}^{3}\right.$ and $1479 \pm 339 \mathrm{~m}^{3}$ respectively for May and November events) decrease significantly considering variable water level and grain sizes (configurations 2 and 3). Due to prevailing erosion during November event at this section, estimate of sediment flux increases using configuration 4. Conversely, configurations 5 and 6 provide almost identical estimations which are notably lower than the previous ones. Using configuration 7 , estimates are $107 \pm 54 \mathrm{~m}^{3}$ and $746 \pm 230 \mathrm{~m}^{3}$ respectively for May and November events. Results, including ranges, for different configurations turn out to be significantly different, at least considering the simplest (i.e. configuration 1) and the most complete input factors settings (i.e. configurations 6 and 7) with values differing by factors between 2 (November event, section 3) and 20 (May event, section 1).

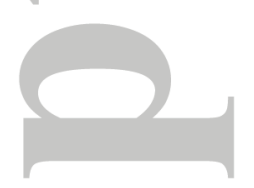

Finally, we were able to distinguish the contribution of partial transport and full transport to the total bed material load estimates (table 2). Ratio PT/FT depends on the event intensity (lower ratios for more intense events) and section morphology (lower for section 3 were the mobility thresholds are lower) but also by the adopted configuration: FT contribution decreases moving from the simplest to the more complex configurations. The estimates variability vary depending on the predominant transport condition that occurred during the considered event. For events characterized by predominant full transport contribution 
(PT/FT<50\%), uncertainty ranges around $25-40 \%$ (considering all configurations), whereas it increases up to $50 \%$ for calculation characterized by predominant partial transport contribution.

\section{Discussion}

4.1 Methodological improvements

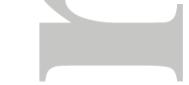

The virtual velocity approach is an estimation method based on a theoretical framework and substantial field-data collection. For this reason we think that it can be defined as a hybrid method. Bed material load is characterized by high variations in rate at local spatial scale (Clayton \& Pitlick, 2007; Ryan \& Dixon, 2007) due to differences in channel material characteristics, sediment supply and local hydraulics. For this reason, identifying an appropriate spatial scale for collecting and analyzing field-data represents a crucial point to apply this approach. Considering data from the Parma River, it is worth noting that all the field-collected parameters are characterized by non-uniformity at the study area scale. $\tau^{*}$ processes thresholds are different considering the whole dataset or sub-datasets and statistically different empirical relations have been obtained distinguishing data collected from upstream and downstream sections. The two couples of cross-sections are located within two distinct reaches (sensu Brierley and Fryirs, 2013), different in terms of morphology and sediments (Figure 1). Our results suggest that the reach, which is homogeneous in terms of morphology and hydraulic characteristics (Grabowski et. al, 2014), should represent the best scale for field-data processing (i.e. definition of the empirical relations between $\tau^{*}$ and the calculation parameters). Differently from Mao et al. (2017), 
which elaborated jointly data collected at different locations, empirical relations and rating curves derived in this study could be considered as "reach-specific relations". We observed uniformity within subset of data collected from sections 1-2 (upstream reach) and sections 34 (downstream reach) with a variable internal data-scattering (e.g. Figures (7) and (8)) due to the variability of sediment transport mechanisms at local scale. Considering this internal variability (described also by Ferguson, 2003), we were able to define uncertainties bands for empirical relations and rating curves and, ultimately, determining variability of transport estimates. The calculated unit bed material loads and section-fluxes can differ from the actual instantaneous transport, characterized by variability also under constant water discharge (Ashmore, 1985, 2013), but our estimates and associated uncertainties represent the mean transport values under determined conditions, having been derived from study sites experiencing various morphodynamic processes, providing reliable transport values at the section spatial-scale and transport-event time-scale.

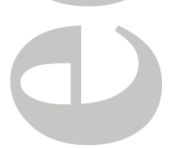

For the virtual velocity empirical relations, it is crucial to determine the particle displacement lengths. Collecting reliable grain travel distances is in turn crucial for achieving sound transport estimates. Most of the previous estimation studies based on the virtual velocity approach employed one tracer type at time (e.g. Liébault \& Laronne (2008), Mao et al. (2017) and Milan (2013) seeded painted clasts; Haschenburger and Church (1998) seeded magnetically-tagged stones): for the first time, we used in combination painted clasts and PIT tags. Our results confirm that PITs recovery rates are high $(>80 \%)$ for all mobility conditions (Chapuis et al., 2014), whereas painted clasts recovery is broadly variable (i.e. from $0 \%$ to 100\%) in relation with transport magnitude (in accordance with Hassan \& Church, 1992, and Hassan \& Roy, 2016). PIT data, although less in number if compared with those obtained 
from painted clasts, can be assumed to represent the real distances traveled by grains due to their excellent technical performances allowing to recover also tagged clasts which, starting from the bed surface, are buried during the first displacement. As shown in Figure 8, for low mobility condition painted clasts and PITs gave similar travel distances, whereas for high mobility (i.e. intense full transport as in Figure 8e and 8f) only PITs provided data. Painted clast tracers provide a large amount of data regarding all grain sizes in response to lowmoderate transport conditions whereas PIT tags provide data, limited in number and in grain size, for all transport conditions giving key information about intense transport processes and validating painted clasts data. From these observations it is possible to conclude that jointly processing displacement length data collected using the two tracer types (considering only tracers which start from the bed surface) is both feasible and effective.

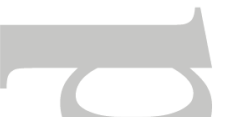

4.2 Calculation parameters: comparisons with previous field studies

For evaluating the reliability of the derived empirical relations between the calculationparameters and the $\tau^{*}$, we compared our data with those collected in other gravel-bed rivers using similar field techniques. The lack of independent data to control the quality of our estimates makes this comparison particularly useful for supporting the following transport estimates. Relations between $\tau^{*}$ and $Y$ (equations (7) and (8)) are in the same range of the equation obtained by Mao et al. (2017) (Figure 7a). The thickness of the active layer (equations (9) and (10)) is comparable with that observed in other studies (see Figure 7b), although at high $\tau^{*}(>0.11)$ our relations suggest the establishment of a thicker active layer. Finally, the unit bed material load curves show a weaker increase with $\tau^{*}$ than the Wilcock \& Crowe (2003) equation whereas the rate of increase appears to be somewhat larger than in the study by Mao et al. (2017) for higher $\tau^{*}(>0.08)$ (Figure 10c). The steepness of transport 
rating curves can be variable for different field sites (Schneider et al., 2015): in our case at high $\tau^{*}$ the active layer is quite thick, and this could explain the high unit-transport when the tractive forces acting on the bed became stronger. Considering that site-specific characteristics (e.g. sediments structure, armoring, fabric) control the local mobility of the streambed material, these comparisons support the reliability of our empirical relations and transport estimates.

4.3 Data configurations and role of different factors

In order to apply the virtual velocity approach at our real case study, differently from Mao et al. (2017) that used only a single configuration, several factors have been considered through a series of input factor configurations (table 1). As reported in table 2, starting from the simplest model setting, estimated bed material transport tended to decrease including factors leading to a more realistic description of channel processes. Comparing the simplest and the most complete configuration results, the obtained variations are significant also considering the natural variability of the transport processes expressed by the estimated uncertainties. The variability of the estimates induced by the adoption of different configurations at specific sections and for specific events (from factors of 2 to 20) is due to the local characteristics of the channel and to the effects induced by each application factor for different competent floods. This suggests that including some key factors could be crucial in order to achieve reliable estimates but to confirm this hypothesis it is necessary to have transport data that can be considered as the real flux.

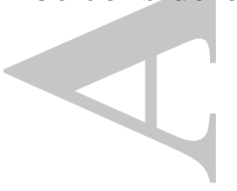


Focusing on the single factors and considering the estimated variations obtained for different configurations, insights on the role played by different factors in the virtual velocity approach calculation have been obtained for the first time through a preliminary sensitivity analysis. Adopting water stages distinctly defined for specific channel units (Figure 5) produced significant estimate variations (up to $-22 \%$ ) only for section 3, located in the wandering downstream reach. As confirmed from our water stage monitoring results (Figures 5 and 6), the assumption of a section-averaged water level represents a simplification, as water levels at a given discharge often differ between adjacent anabranches in multi-thread channels (e.g. Zolezzi et al., 2006). Increasing channel morphology complexity the in-section water stage variability becomes a crucial parameter in order to obtain reliable estimates of $\tau^{*}$. Similar results about the impact of using width-averaged or local definition of the $\tau$ induced by the water flow on the transport estimates were reported also by Ferguson (2003).

The significant variations (between $-24 \%$ and $-94 \%$ ) obtained introducing geomorphic unit specific $D_{50}$ to calculate the $\tau^{*}$ active on the streambed lead to consider sediments grain size as the most important factor influencing the approach application. Fernández and Garcia (2017) achieved similar results by a theoretical sensitivity assessment for two sediment transport relations concluding that an accurate knowledge of sediment size has more impact on transport predictions than other input variables. The local grain size represents in fact a fundamental variable in the $\tau^{*}$ calculation (equation 4). Section 1 estimates are strongly affected by this factor (variations up to $-94 \%$ ), in comparison to section 3 (variation up to $50 \%$ ). This different response may be due to the higher armoring occurring in the main channel in the middle-upstream part of the study sector, suggesting that high grain size variations at cross-section scale (e.g. between main channel and bars) can strongly influence 
transport intensity and its estimation. Considering the high variability characterizing both longitudinally (Mosley \& Tindale, 1985; Rice \& Church, 1998; Surian, 2002) and transversally (Rice \& Church, 2010) the streambed material grain sizes in gravel-bed rivers and the occurrence of armoring conditions (Hassan et al., 2006), an accurate description of this variable is strongly demanded. Combining water stages distinctly defined for channel zones and geomorphic unit specific $D_{50}$ (see configuration 5 in table 2), the obtained estimate variations (between $-56 \%$ and - 94\%) confirm the crucial role of these factors.

The last factor considered in this work are topographic variations occurring at a given crosssection during a transporting event. When only partial transport occurred, section topography did not experience elevation changes and, therefore, estimates were not influenced by this factor. For events inducing full transport, the influence of this factor is strictly controlled by the elevation changes that occurred within the section and its positive or negative impact on estimates depends by the predominant erosional or depositional processes. During the November 2016 event both sections experienced intense full transport, but section 1 was in equilibrium (no change in mean section elevation, max erosion $=-130 \mathrm{~mm}$, max deposition= $+85 \mathrm{~mm}$ ) whereas section 3 underwent some incision (mean section elevation variation $=-6$ $\mathrm{mm}$, max erosion $=-280 \mathrm{~mm}$, max deposition $=+155 \mathrm{~mm}$ ). Cross-section variations led to a small estimate increase for section $1(+0.5 \%)$ and to a more significant variation $(+19 \%)$ for section 3. Such results suggest that topographic variations can affect estimates only for intense transport event and in reaches featuring disequilibrium conditions in sediment transport leading to erosion or aggradation of channel bed (Kondolf, 1997; Grant, 2012).

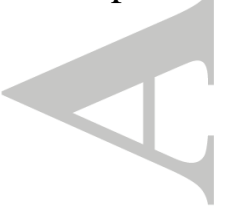


4.4 Limitations, wider implications and future perspectives for the virtual velocity approach

Reliable field data are essential for applying the virtual velocity approach but some methodological issues persist in data collection. One of the most difficult variables to monitor remains the active layer thickness: scour chains provide few data and topographic surveys can lead to underestimation of the thickness due to scour and fill compensation over a single hydrograph (see Figure 7b). For these reasons, it would be desirable to test alternative solutions: some promising attempts were carried out by using sliding-balls (Nawa \& Frissell, 1993) or buried accelerometers (DeVries et al., 2001; Gendaszek et al., 2013). Haschenburger (1996, 2011) used the burial depth of tracers to describe the gravel vertical mixing, suggesting that some improvements in the active layer thickness parametrization could be achieved considering the buried PITs recovering depths.

Tractive forces active on the streambed lead most of the transport processes considered through this approach. Instead of just considering local hydrographs and cross-section topography, more sophisticated $\tau^{*}$ calculation could be applied using numerical hydraulic models (e.g. Bockelmann et al., 2004; Booker et al., 2001). To allow this calculation, digital terrain models and reliable hydrological data are required (Aggett \& Wilson, 2009; Formann et al., 2007; Teng et al., 2017), coupled with detailed local grain size information. Considering the results recently achieved about the importance of the larger clasts in determining the mobility of the streambed material (MacKenzie at al., 2018), it could be useful to explore the use of different grain sizes instead of the commonly adopted $D_{50}$ for $\tau^{*}$ calculation.

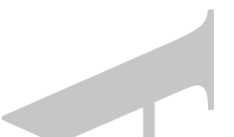

The clasts mobility-data considered in our work derive mainly from study sites installed in correspondence of bars and secondary channels due to the difficulties in installation and 
recovery of passive tracers within channel portions submerged during low-flow conditions (only 11 out of 117 study sites were installed within the main channel). It is likely that our empirical relations could be improved obtaining a better description of sediment dynamics within the main channel for instance by employing active tracers as in Cassel et al. (2017).

Other limitations affect the virtual velocity approach, being it a simplified hybrid estimation method. From our uncertainty analysis we partially considered the different morphodynamic processes active in the channel, but the bed morphology complexity, typical of large gravelbed rivers, leads to non-uniformity of particle mobility dynamics (Marti \& Bezzola, 2006; Recking et al., 2016). Some improvements have been achieved by calculation of instantaneous and local $\tau^{*}$, but several issues persist, for instance in the calculation of the local competent flow duration as the above-critical $\tau^{*}$ period (e.g. as done by Haschenburger and Church, 1998), considering that the grains mobility can be influenced by the complex bed topography during the event (Church, 2006). Improvements could be achieved adopting the procedure developed by Klösch and Habersack (2018) to calculate unsteady virtual velocity from repeated surveys of tracer positions. Another virtual velocity calculation weakness is due to the exclusive use of tracers starting at the bed surface, which move more easily than the average grains in the active layer mobilized during full transport (Vázquez-Tarrío et al., 2018). As explained by Ferguson and Hoey (2002), if tracers are not fully mixed into the bed the calculated virtual velocity can be overestimated leading to full transport flux overestimate of high-magnitude events. Some improvements will be possible considering long term tracers dispersion (Haschenburger, 2013b) and relation between morphology and tracers mobility (Papangelakis \& Hassan, 2016; Vázquez-Tarrío et al., 2018). 
This study has shown some strengths of the virtual velocity approach: it does not require data collection during transport events and it can be applied to wide rivers where alternatives are currently poorly available. The approach is applicable through the proposed transport calculation procedure to a broad spectrum of large gravel-bed rivers, adaptable to specific case-study features using both reach-specific empirical relations and case-specific application factors. The estimate variability obtained from different configurations suggest that the approach (i.e. field monitoring, data processing and transport estimate) requires to be designed according to case-specific aspects, because its sensitivity to different factors varies depending upon reach features. Some procedures remain valid for all contexts, whereas other methodological aspects should be designed according to specific reach morphology, sediments and section stability over the time. With this in mind, we propose a decision tree describing the field measures and elaborations required to deal with the application factors which have an impact on transport estimate (Figure 11). Looking at the different configurations estimates for the different sections and events (Table 2), it is possible to observe that in some cases, considering the uncertainties, it is not essential to adopt the most complete configuration, since also a simpler configuration could be sufficient for taking into account all the case-specific key-factors. For instance, at section 1, characterized by singlethread morphology and stable topography, only the in-section variable $D_{50}$ represents a keyfactor: in fact, configurations 3 and 7 give very similar results (Table 2). On the contrary, all the factors (configuration 7) need to be included for a sound assessment of sediment transport at section 3 during the November 2017 event. The field monitoring and data elaboration efforts strongly depend by the adopted input factor configuration. For this reason we reported the simplest required configuration to be adopted for some river contexts in the decision tree (Figure 11). 


\section{Conclusions}

It is widely accepted that using formulas for estimating bed material transport can led to calculation errors (e.g. Barry et al, 2004; Fernández \& Garcia, 2017) and other techniques are currently poorly available for large gravel-bed rivers (the morphological approach represents the only exception, although its application has some constrains). The virtual velocity approach provides an alternative to trapping techniques (difficult to employ in wide complex rivers) that incorporates some key factors of channel morphology and processes and it is strongly based on field data. Developing robust and widely applicable transport-estimate approaches based on tracers could provide benefits also in the perspective of integrating their data with $3 \mathrm{D}$ change detection approaches (e.g. morphological method based on digital elevation models) to advance the work further (Vericat et al., 2017).

This work aimed to assess the virtual velocity approach, evaluating the significance of factors that feed in the transport calculation through a sensitivity analysis. The main conclusions from this study are:

1. We highlighted some crucial issues of the monitoring activity in order to derive sound relationships between a set of calculation parameters and the leading variables. Adopting appropriate spatial scales for data collection and processing (i.e. reaches for empirical relationships and geomorphic units for grain size definition) and the jointly use of painted particles and PITs are two fundamental monitoring strategies.

2. Using simple data input configurations or more complex ones may lead to significant differences in transport estimates. On the other hand, in relation to channel morphodynamics, different factors play a key-role on transport processes. The proposed "decision tree" can be considered as a first attempt towards a more effective 
use of the virtual velocity approach to estimate bed material load in a broad spectrum of large gravel-bed rivers.

3. We considered the natural transport processes variability evaluating the estimate uncertainties from field-data distributions. Future efforts should be addressed to consider more in detail the complex morphodynamics of large gravel-bed rivers, including a more realistic unsteady virtual velocity calculation and the influence of local morphology on tracers mobility trying also to expand the sensitivity analysis.

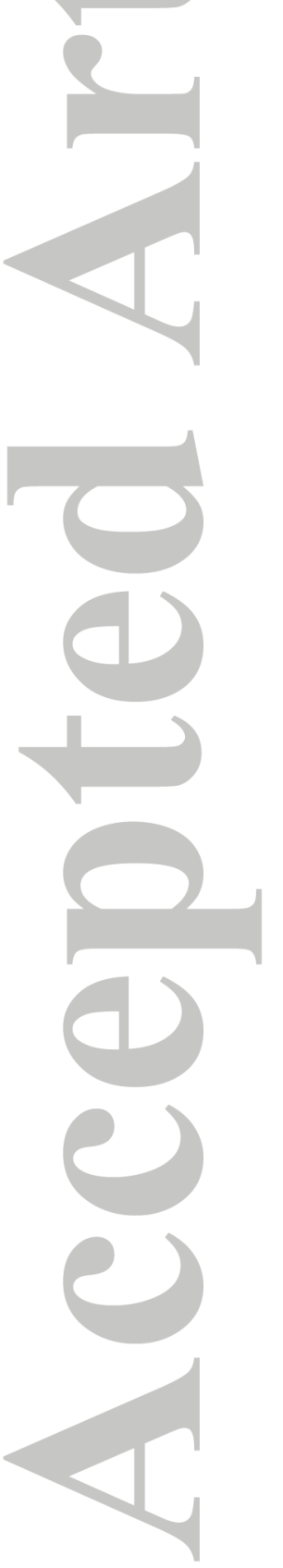




\section{References}

Aggett, G. R., \& Wilson, J. P. (2009). Creating and coupling a high-resolution DTM with a 1D hydraulic model in a GIS for scenario-based assessment of avulsion hazard in a gravel-bed river. Geomorphology, 113(1), 21-34. https://doi.org/10.1016/j.geomorph.2009.06.034

Ashmore, P. E. (1985). Process and form in gravel braided streams: laboratory modelling and field observations, (Doctoral dissertation). Edmonton, Canada: University of Alberta.

Ashmore, P. E. (1988). Bed load transport in braided gravel-bed stream models. Earth Surface Processes and Landforms, 13(8), 677-695. https://doi.org/10.1002/esp.3290130803

Ashmore, P. E. (2013). Morphology and dynamics of braided rivers. In J. F. Shroder (Ed.), Treatise on Geomorphology, Vol. 9 (pp. 289-312). Amsterdam, Netherlands: Elsevier.

Ashmore, P. E., \& Church, M. (1998). Sediment transport and river morphology: a paradigm for study. In P. C. Klingeman, R. L. Beschta, P. D. Komar, J. B. Bradley (Eds.), Gravel-Bed Rivers in the Environment (pp. 115-148). Highlands Ranch, CO: Water Resources Publications LLC

Barry, J. J., Buffington, J. M., \& King, J. G. (2004). A general power equation for predicting bed load transport rates in gravel bed rivers. Water Resources Research, 40(10). https://doi.org/10.1029/2004WR003190

Belletti, B., Rinaldi, M., Bussettini, M., Comiti, F., Gurnell, A. M., Mao, L., \& Vezza, P. (2017). Characterising physical habitats and fluvial hydromorphology: A new system for the survey and classification of river geomorphic units. Geomorphology, 283, 143-157. https://doi.org/10.1016/j.geomorph.2017.01.032

Bockelmann, B. N., Fenrich, E. K., Lin, B., \& Falconer, R. A. (2004). Development of an ecohydraulics model for stream and river restoration. Ecological Engineering, 22(4), 227235. https://doi.org/10.1016/j.ecoleng.2004.04.003

Booker, D. J., Sear, D. A., \& Payne, A. J. (2001). Modelling three- dimensional flow structures and patterns of boundary shear stress in a natural pool-riffle sequence. Earth Surface Processes and Landforms, 26(5), 553- https://doi.org/576. 10.1002/esp.210 
Bradley, D. N., \& Tucker, G. E. (2012). Measuring gravel transport and dispersion in a mountain river using passive radio tracers. Earth Surface Processes and Landforms, 37(10), 1034-1045. https://doi.org/10.1002/esp.3223

Brasington, J., Langham, J., \& Rumsby, B. (2003). Methodological sensitivity of morphometric estimates of coarse fluvial sediment transport. Geomorphology, 53(3), 299316. https://doi.org/10.1016/S0169-555X(02)00320-3

Brierley, G. J., \& Fryirs, K. A. (2013). Geomorphology and river management: applications of the river styles framework. Hoboken, NJ: John Wiley \& Sons

Bunte, K., \& Abt, S. R. (2001). Sampling surface and subsurface particle-size distributions in wadable gravel-and cobble-bed streams for analyses in sediment transport, hydraulics, and streambed monitoring. Gen. Tech. Rep. RMRS-GTR-74. Fort Collins, CO: U.S. Department of Agriculture, Forest Service, Rocky Mountain Research Station. https://doi.org/10.2737/RMRS-GTR-74

Bunte, K., Abt, S. R., Potyondy, J. P., \& Ryan, S. E. (2004). Measurement of coarse gravel and cobble transport using portable bedload traps. Journal of Hydraulic Engineering, 130(9), 879-893. https://doi.org/10.1061/(ASCE)0733-9429(2004)130:9(879)

Bunte, K., Swingle, K. W., \& Abt, S. R. (2007). Guidelines for using bedload traps in coarsebedded mountain streams: construction, installation, operation, and sample processing. Gen. Tech. Rep. RMRS-GTR-191. Fort Collins, CO: U.S. Department of Agriculture, Forest Service, Rocky Mountain Research Station. https://doi.org/10.2737/RMRS-GTR-191

Bunte, K., Abt, S. R., Potyondy, J. P., \& Swingle, K. W. (2008). A comparison of coarse bedload transport measured with bedload traps and Helley-Smith samplers. Geodinamica Acta, 21(1-2), 53-66. https://doi.org/10.3166/ga.21.53-66

Carling, P.A. (1987). Bed stability in gravel streams, with reference to stream regulation and ecology. In K.S. Richards (Ed.), Rivers, from and process in alluvial channels (pp. 321-347). London, UK: Methuen.

Carling, P. A., \& Reader, N. A. (1982). Structure, composition and bulk properties of upland stream gravels. Earth Surface Processes and Landforms, 7(4), 349-365. https://doi.org/10.1002/esp.3290070407 
Cassel, M., Dépret, T., \& Piégay, H. (2017). Assessment of a new solution for tracking pebbles in rivers based on active RFID. Earth Surface Processes and Landforms, 42(13), 1938-1951. https://doi.org/10.1002/esp.4152

Chapuis, M., Bright, C. J., Hufnagel, J., \& MacVicar, B. (2014). Detection ranges and uncertainty of passive Radio Frequency Identification (RFID) transponders for sediment tracking in gravel rivers and coastal environments. Earth Surface Processes and Landforms, 39(15), https://doi.org/2109-2120. 10.1002/esp.3620

Chapuis, M., Dufour, S., Provansal, M., Couvert, B., \& De Linares, M. (2015). Coupling channel evolution monitoring and RFID tracking in a large, wandering, gravel-bed river: Insights into sediment routing on geomorphic continuity through a riffle-pool sequence. Geomorphology, 231, 258-269. https://doi.org/10.1016/j.geomorph.2014.12.013

Church, M. (2006). Bed material transport and the morphology of alluvial river channels. Annu. Rev. Earth Planet. Sci., 34, 325-354. https://doi.org/10.1146/annurev.earth.33.092203.122721

Church, M., \& Ferguson, R. I. (2015). Morphodynamics: Rivers beyond steady state. Water Resources Research, 51(4), 1883-1897. https://doi.org/10.1002/2014WR016862

Church, M., \& Hassan, M. A. (1992). Size and distance of travel of unconstrained clasts on a streambed. Water Resources Research, 28(1), 299-303. https://doi.org/10.1029/91WR02523

Church, M., \& Haschenburger, J. K. (2017). What is the "active layer"?. Water Resources Research, 53(1), 5-10. https://doi.org/10.1002/2016WR019675

Clayton, J. A., \& Pitlick, J. (2007). Spatial and temporal variations in bed load transport intensity in a gravel bed river bend. Water Resources Research, 43(2). https://doi.org/10.1029/2006WR005253

Cudden, J. R., \& Hoey, T. B. (2003). The causes of bedload pulses in a gravel channel: The implications of bedload grain-size distributions. Earth Surface Processes and Landforms, 28(13), 1411-1428. https://doi.org/10.1002/esp.521

DeVries, P. (2002). Bedload layer thickness and disturbance depth in gravel bed streams. Journal of Hydraulic Engineering, 128(11), 983-991. https://doi.org/10.1061/(ASCE)0733-9429(2002)128:11(983) 
DeVries, P., Burges, S. J., Daigneau, J., \& Stearns, D. (2001). Measurement of the temporal progression of scour in a pool- riffle sequence in a gravel bed stream using an electronic scour monitor. Water Resources Research, 37(11), 2805-2816. https://doi.org/10.1029/2001WR000357

Ferguson, R. I. (2003). The missing dimension: effects of lateral variation on 1-D calculations of fluvial bedload transport. Geomorphology, 56(1-2), 1-14. https://doi.org/10.1016/S0169-555X(03)00042-4

Ferguson, R. I. (2007). Gravel-bed rivers at the reach scale. In H. Habersack, H. Piégay, M. Rinaldi (Eds.), Gravel-bed Rivers VI: from process understanding to river restoration (pp. 33-60). Amsterdam, Netherlands: Elsevier.

Ferguson, R. I., \& Hoey, T. B. (2002). Long-term slowdown of river tracer pebbles: Generic models and implications for interpreting short-term tracer studies. Water Resources Research,38(8). https://doi.org/10.1029/2001WR000637

Ferguson, R. I., \& Wathen, S. J. (1998). Tracer- pebble movement along a concave river profile: Virtual velocity in relation to grain size and shear stress. Water Resources Research, 34(8), 2031-2038. https://doi.org/10.1029/98WR01283

Fernández, R., \& Garcia, M.H. (2017). Input-variable sensitivity assessment for sediment transport relations. Water Resources Research, 53. https://doi.org/10.1002/2016WR020249.

Formann, E., \& Habersack, H. M. (2007). Morphodynamic river processes and techniques for assessment of channel evolution in Alpine gravel bed rivers. Geomorphology, 90(3), 340355. https://doi.org/10.1016/j.geomorph.2006.10.029

Gendaszek, A. S., Magirl, C. S., Czuba, C. R., \& Konrad, C. P. (2013). The timing of scour and fill in a gravel-bedded river measured with buried accelerometers. Journal of Hydrology, 495, 186-196. https://doi.org/10.1016/j.jhydrol.2013.05.012

Grabowski, R. C., Surian, N., \& Gurnell, A. M. (2014). Characterizing geomorphological change to support sustainable river restoration and management. Wiley Interdisciplinary Reviews: Water, 1(5), 483-512. https://doi.org/10.1002/wat2.1037

Gomez, B., \& Church, M. (1989). An assessment of bed load sediment transport formulae for gravel bed rivers. Water Resources Research, 25(6), 1161-1186. https://doi.org/10.1029/WR025i006p01161 
Graham, D. J., Reid, I., \& Rice, S. P. (2005a). Automated sizing of coarse-grained sediments: image-processing procedures. Mathematical Geology, 37(1), 1-28. https://doi.org/10.1007/s11004-005-8745-x

Graham, D. J., Rice, S. P., \& Reid, I. (2005b). A transferable method for the automated grain sizing of river gravels. Water Resources Research, 41(7). https://doi.org/10.1029/2004WR003868

Graham, D. J., Rollet, A. J., Piégay, H., \& Rice, S. P. (2010). Maximizing the accuracy of image- based surface sediment sampling techniques. Water Resources Research, 46(2). https://doi.org/10.1029/2008WR006940

Grant, G. E. (2012). The geomorphic response of gravel- bed rivers to dams: perspectives and prospects. In M. Church, P. M. Biron, A. G. Roy (Eds.), Gravel-bed Rivers: Processes, Tools, Environments (pp. 165-181). Hoboken, NJ: John Wiley \& Sons

Haschenburger, J. K. (1996). Scour and fill in a gravel-bed channel: observations and stochastic models, (Doctoral dissertation). Retrieved from https://open.library.ubc.ca/. Vancouver, Canada: University of British Columbia

Haschenburger, J. K. (2011). Vertical mixing of gravel over a long flood series. Earth Surface Processes and Landforms, 36(8), 1044-1058. https://doi.org/10.1002/esp.2130

Haschenburger, J. K. (2013a). Bedload kinematics and fluxes. In J. F. Shroder (Ed.), Treatise on Geomorphology, Vol. 9 (pp. 103-123). Amsterdam, Netherlands: Elsevier.

Haschenburger, J. K. (2013b). Tracing river gravels: Insights into dispersion from a longterm field experiment. Geomorphology, 200, 121-131. https://doi.org/10.1016/j.geomorph.2013.03.033

Haschenburger, J. K., \& Church, M. (1998). Bed material transport estimated from the virtual velocity of sediment. Earth Surface Processes and Landforms, 23(9), 791-808. https://doi.org/10.1002/(SICI)1096-9837(199809)23:9<791::AID-ESP888>3.0.CO;2-X

Haschenburger, J. K., \& Wilcock, P. R. (2003). Partial transport in a natural gravel bed channel. Water Resources Research, 39(1). https://doi.org/10.1029/2002WR001532 
Hassan, M. A., \& Bradley, D. N. (2017). Geomorphic Controls on Tracer Particle Dispersion in Gravel-Bed Rivers. In D. Tsutsumi, J. B. Laronne (Eds.), Gravel-Bed Rivers: Processes and Disasters (pp. 209-233). Hoboken, NJ: John Wiley \& Sons

Hassan, M. A., \& Church, M. (1992). The movement of individual grains on the streambed. In P. Billi, R. D. Hey, C. R. Thorne, P. Tacconi (Eds.), Dynamics of gravel-bed rivers (pp. 159-175). Hoboken, NJ: John Wiley \& Sons. https://doi.org/10.1002/esp.3290180510

Hassan, M. A., Egozi, R., \& Parker, G. (2006). Experiments on the effect of hydrograph characteristics on vertical grain sorting in gravel bed rivers. Water Resources Research, 42(9). https://doi.org/10.1029/2005WR004707

Hassan, M. A., \& Roy, A. G. (2016). Coarse particle tracing in fluvial geomorphology. In G.M. Kondolf, H. Piégay (Eds.), Tools in fluvial geomorphology (pp. 306-323). Hoboken, NJ: John Wiley \& Sons. https://doi.org/10.1002/9781118648551.ch14

Helley, E. J., \& Smith, W. (1971). Development and calibration of a pressure-difference bedload sampler. Open-File Report (No. 73-108). Menlo Park, CA: Water Resour. Div., U. S. Geol. Surv. https://doi.org/10.3133/ofr73108

Hoey, T. (1992). Temporal variations in bedload transport rates and sediment storage in gravel-bed rivers. Progress in physical geography, 16(3), 319-338. https://doi.org/10.1177/030913339201600303

Houbrechts, G., Van Campenhout, J., Levecq, Y., Hallot, E., Peeters, A., \& Petit, F. (2012). Comparison of methods for quantifying active layer dynamics and bedload discharge in armoured gravel- bed rivers. Earth Surface Processes and Landforms, 37(14), 1501-1517. https://doi.org/10.1002/esp.3258

Kasprak, A., Wheaton, J. M., Ashmore, P. E., Hensleigh, J. W., \& Peirce, S. (2015). The relationship between particle travel distance and channel morphology: Results from physical models of braided rivers. Journal of Geophysical Research: Earth Surface, 120(1), 55-74. https://doi.org/10.1002/2014JF003310

Klösch, M., \& Habersack, H. (2018). Deriving formulas for an unsteady virtual velocity of bedload tracers. Earth Surface Processes and Landforms, 43, 1529-1541. https://doi.org/10.1002/esp.4326 
Kondolf, G. M. (1997). Hungry water: effects of dams and gravel mining on river channels. Environmental management, 21(4), 533-551. https://doi.org/10.1007/s002679900048

Lamarre, H., MacVicar, B., \& Roy, A. G. (2005). Using passive integrated transponder (PIT) tags to investigate sediment transport in gravel-bed rivers. Journal of Sedimentary Research, 75(4), 736-741. https://doi.org/10.2110/jsr.2005.059

Lane, S. N., Richards, K. S., \& Chandler, J. H. (1995). Morphological Estimation of the Time- Integrated Bed Load Transport Rate. Water Resources Research, 31(3), 761-772. https://doi.org/10.1029/94WR01726

Laronne, J. B., Outhet, D. N., Carling, P. A., \& McCabe, T. J. (1994). Scour chain employment in gravel bed rivers. Catena, 22(4), 299-306. https://doi.org/10.1016/03418162(94)90040-X

Liébault, F., Bellot, H., Chapuis, M., Klotz, S., \& Deschâtres, M. (2012). Bedload tracing in a high- sediment- load mountain stream. Earth Surface Processes and Landforms, 37(4), 385399. https://doi.org/10.1002/esp.2245

Liébault, F., \& Laronne, J. B. (2008). Evaluation of bedload yield in gravel-bed rivers using scour chains and painted tracers: the case of the Esconavette Torrent (Southern French Prealps). Geodinamica Acta, 21(1-2), 23-34. https://doi.org/10.3166/ga.21.23-34

Lindsay, J. B., \& Ashmore, P. E. (2002). The effects of survey frequency on estimates of scour and fill in a braided river model. Earth Surface Processes and Landforms, 27(1), 27-43. https://doi.org/10.1002/esp.282

López, R., Vericat, D., \& Batalla, R. J. (2014). Evaluation of bed load transport formulae in a large regulated gravel bed river: The lower Ebro (NE Iberian Peninsula). Journal of hydrology, 510, 164-181. https://doi.org/10.1016/j.jhydrol.2013.12.014

MacKenzie, L. G., Eaton, B. C., \& Church, M (2018). Breaking from the average: Why large grains matter in gravel-bed streams. Earth Surface Processes and Landforms. https://doi.org/10.1002/esp.4465

Mao, L., \& Surian, N. (2010). Observations on sediment mobility in a large gravel-bed river. Geomorphology, 114(3), 326-337. https://doi.org/10.1016/j.geomorph.2009.07.015 
Mao, L., Picco, L., Lenzi, M. A., \& Surian, N. (2017). Bed material transport estimate in large gravel- bed rivers using the virtual velocity approach. Earth Surface Processes and Landforms, 42(4), 595-611. https://doi.org/10.1002/esp.4000

Marti, C., \& Bezzola, G. R. (2006). Bed load transport in braided gravel-bed rivers. In G.H. Sambrook Smith, J.L. Best, C.S. Bristow, G.E. Petts (Eds.), Braided rivers: Processes, Deposits, Ecology and Management (pp. 199-215). Oxford, UK: Blackwell Publishing Ltd

Martin, Y., \& Church, M. (1995). Bed-material transport estimated from channel surveys: Vedder River, British Columbia. Earth Surface Processes and Landforms, 20(4), 347-361. https://doi.org/10.1002/esp.3290200405

Martin, Y., \& Ham, D. (2005). Testing bedload transport formulae using morphologic transport estimates and field data: lower Fraser River, British Columbia. Earth Surface Processes and Landforms, 30(10), 1265-1282. https://doi.org/10.1002/esp.1200

McLean, D. G., \& Church, M. (1999). Sediment transport along lower Fraser River: 2. Estimates based on the long- term gravel budget. Water Resources Research, 35(8), 25492559. https://doi.org/10.1029/1999WR900102

Merz, J. E., Pasternack, G. B., \& Wheaton, J. M. (2006). Sediment budget for salmonid spawning habitat rehabilitation in a regulated river. Geomorphology, 76(1), 207-228. https://doi.org/10.1016/j.geomorph.2005.11.004

Milan, D. J. (2013). Virtual velocity of tracers in a gravel-bed river using size-based competence duration. Geomorphology, 198, 107-114. https://doi.org/10.1016/j.geomorph.2013.05.018

Mosley, M. P., \& Tindale, D. S. (1985). Sediment variability and bed material sampling in gravel- bed rivers. Earth Surface Processes and Landforms, 10(5), https://doi.org/465-482. 10.1002/esp.3290100506

Mueller, E. R., Pitlick, J., \& Nelson, J. M. (2005). Variation in the reference Shields stress for bed load transport in gravel- bed streams and rivers. Water Resources Research, 41(4). https://doi.org/10.1029/2004WR003692

Nawa, R. K., \& Frissell, C. A. (1993). Measuring scour and fill of gravel streambeds with scour chains and sliding-bead monitors. North American Journal of Fisheries Management, 13(3), 634-639. http://dx.doi.org/10.1577/1548-8675(1993)013<0634:MSAFOG>2.3.CO;2 
Papangelakis, E., \& Hassan, M. A. (2016). The role of channel morphology on the mobility and dispersion of bed sediment in a small gravel-bed stream. Earth Surface Processes and Landforms, 41(15), 2191-2206. https://doi.org/10.1002/esp.3980

Parker, G. (1990). Surface-based bedload transport relation for gravel rivers. Journal of hydraulic research, 28(4), 417-436. https://doi.org/10.1080/00221689009499058

Petit, F. (1987). The relationship between shear stress and the shaping of the bed of a pebbleloaded river La Rulles-Ardenne. Catena, 14(5), 453-468. https://doi.org/10.1016/03418162(87)90015-4

Pyrce, R. S., \& Ashmore, P. E. (2003a). Particle path length distributions in meandering gravel- bed streams: Results from physical models. Earth Surface Processes and Landforms, 28(9), 951-966. https://doi.org/10.1002/esp.498

Pyrce, R. S., \& Ashmore, P. E. (2003b). The relation between particle path length distributions and channel morphology in gravel-bed streams: a synthesis. Geomorphology, 56(1-2), 167-187. https://doi.org/10.1016/S0169-555X(03)000771

Recking, A., Liébault, F., Peteuil, C., \& Jolimet, T. (2012). Testing bedload transport equations with consideration of time scales. Earth Surface Processes and Landforms, 37(7), 774-789. https://doi.org/10.1002/esp.3213

Recking, A., Piton, G., Vazquez-Tarrio, D., \& Parker, G. (2016). Quantifying the morphological print of bedload transport. Earth Surface Processes and Landforms, 41(6), 809-822. https://doi.org/10.1002/esp.3869

Rennie, C. D., \& Villard, P. V. (2004a). Site specificity of bed load measurement using an acoustic Doppler current profiler. Journal of Geophysical Research: Earth Surface, 109(F3). https://doi.org/10.1029/2003JF000106

Rennie, C. D., \& Millar, R. G. (2004b). Measurement of the spatial distribution of fluvial bedload transport velocity in both sand and gravel. Earth Surface Processes and Landforms, 29(10), 1173-1193. https://doi.org/10.1002/esp.1074

Rennie, C. D., Vericat, D., Williams, R. D., Brasington, J., \& Hicks, M. (2017). Calibration of acoustic doppler current profiler apparent bedload velocity to bedload transport rate. In D. 
Tsutsumi, J. B. Laronne (Eds.), Gravel-Bed Rivers: Processes and Disasters (pp. 209-233). Hoboken, NJ: John Wiley \& Sons

Rice, S., \& Church, M. (1998). Grain size along two gravel- bed rivers: statistical variation, spatial pattern and sedimentary links. Earth Surface Processes and Landforms, 23(4), 345363. https://doi.org/10.1002/(SICI)1096-9837(199804)23:4<345::AID-ESP850>3.0.CO;2-B

Rice, S. P., \& Church, M. (2010). Grain- size sorting within river bars in relation to downstream fining along a wandering channel. Sedimentology, 57(1), 232-251. https://doi.org/232-251. 10.1111/j.1365-3091.2009.01108.x

Rickenmann, D. (2017). Bedload transport measurements with geophones, hydrophones, and underwater microphones (passive acoustic methods). In D. Tsutsumi, J. B. Laronne (Eds.), Gravel-Bed Rivers: Processes and Disasters (pp. 185-208). Hoboken, NJ: John Wiley \& Sons

Rickenmann, D., Turowski, J. M., Fritschi, B., Wyss, C., Laronne, J., Barzilai, R., \& Habersack, H. (2014). Bedload transport measurements with impact plate geophones: comparison of sensor calibration in different gravel- bed streams. Earth Surface Processes and Landforms, 39(7), 928-942. https://doi.org/10.1002/esp.3499

Ryan, S. E., \& Dixon, M. K. (2007). 15 Spatial and temporal variability in stream sediment loads using examples from the Gros Ventre Range, Wyoming, USA. In H. Habersack, H. Piégay, M. Rinaldi (Eds.), Gravel-Bed Rivers VI: From Process Understanding to River Restoration (pp. 387-407). Amsterdam, Netherlands: Elsevier.

Sear, D. A. (1996). Sediment transport processes in pool-riffle sequences. Earth Surface Processes and Landforms, 21(3), 241-262. https://doi.org/10.1002/(SICI)10969837(199603)21:3<241::AID-ESP623>3.0.CO;2-1

Schneider, J. M., Rickenmann, D., Turowski, J. M., Bunte, K., \& Kirchner, J. W. (2015). Applicability of bed load transport models for mixed-size sediments in steep streams considering macro-roughness. Water Resources Research,51(7), 5260-5283. https://doi.org/10.1002/2014WR016417

Storz-Peretz, Y., \& Laronne, J. B. (2013). Automatic grain sizing of vertical exposures of gravelly deposits. Sedimentary Geology, 294, 13-26. https://doi.org/10.1016/j.sedgeo.2013.05.004 
Surian, N. (2002). Downstream variation in grain size along an Alpine river: analysis of controls and processes. Geomorphology, 43(1), 137-149. https://doi.org/10.1016/S0169$555 \mathrm{X}(01) 00127-1$

Surian, N., \& Cisotto, A. (2007). Channel adjustments, bedload transport and sediment sources in a gravel- bed river, Brenta River, Italy. Earth Surface Processes and Landforms, 32(11), 1641-1656. https://doi.org/10.1002/esp.1591

Surian, N., Mao, L., Giacomin, M., \& Ziliani, L. (2009). Morphological effects of different channel- forming discharges in a gravel- bed river. Earth Surface Processes and Landforms, 34(8), 1093-1107. https://doi.org/10.1002/esp.1798

Teng, J., Jakeman, A. J., Vaze, J., Croke, B. F., Dutta, D., \& Kim, S. (2017). Flood inundation modelling: A review of methods, recent advances and uncertainty analysis. Environmental Modelling \& Software, 90, 201-216. https://doi.org/10.1016/j.envsoft.2017.01.006

Thompson, D. M., \& Wohl, E. E. (2009). The linkage between velocity patterns and sediment entrainment in a forced- pool and riffle unit. Earth Surface Processes and Landforms, 34(2), 177-192. https://doi.org/10.1002/esp.1698

Vázquez-Tarrío, D., Recking, A., Liébault, F., Tal, M., \& Menéndez-Duarte, R (2018). Particle transport in gravel-bed rivers: revisiting passive tracer data. Earth Surface Processes and Landforms. https://doi.org/10.1002/esp.4484

Vericat, D., Church, M., \& Batalla, R. J. (2006). Bed load bias: Comparison of measurements obtained using two (76 and $152 \mathrm{~mm}$ ) Helley- Smith samplers in a gravel bed river. Water Resources Research, 42(1). https://doi.org/10.1029/2005WR004025

Vericat, D., Wheaton, J. M., \& Brasington, J. (2017). Revisiting the Morphological Approach: Opportunities and Challenges with Repeat High-Resolution Topography. In D. Tsutsumi, J. B. Laronne (Eds.), Gravel-Bed Rivers: Processes and Disasters (pp. 121-158). Hoboken, NJ: John Wiley \& Sons

Wheaton, J. M., Brasington, J., Darby, S. E., \& Sear, D. A. (2010). Accounting for uncertainty in DEMs from repeat topographic surveys: improved sediment budgets. Earth Surface Processes and Landforms, 35(2), 136-156. https://doi.org/10.1002/esp.1886 
Wheaton, J. M., Fryirs, K. A., Brierley, G., Bangen, S. G., Bouwes, N., \& O'Brien, G. (2015). Geomorphic mapping and taxonomy of fluvial landforms. Geomorphology, 248, 273-295. https://doi.org/10.1016/j.geomorph.2015.07.010

Wilcock, P. R. (1993). Critical shear stress of natural sediments. Journal of Hydraulic Engineering, 119(4), 491-505. https://doi.org/10.1061/(ASCE)0733-9429(1993)119:4(491)

Wilcock, P. R. (1997). Entrainment, displacement and transport of tracer gravels. Earth Surface Processes and Landforms, 22(12), 1125-1138. https://doi.org/10.1002/(SICI)10969837(199712)22:12<1125::AID-ESP811>3.0.CO;2-V

Wilcock, P. R., Barta, A. F., Shea, C. C., Kondolf, G. M., Matthews, W. V., \& Pitlick, J. (1996). Observations of flow and sediment entrainment on a large gravel-bed river. Water Resources Research, 32(9), 2897-2909. https://doi.org/10.1029/96WR01628

Wilcock, P. R., \& DeTemple, B. T. (2005). Persistence of armor layers in gravel-bed streams. Geophysical Research Letters, 32(8). https://doi.org/10.1029/2004GL021772

Wilcock, P. R., \& McArdell, B. W. (1997). Partial transport of a sand/gravel sediment. Water Resources Research, 33(1), 235-245. https://doi.org/10.1029/96WR02672

Wilcock, P. R., \& Crowe, J. C. (2003). Surface-based transport model for mixed-size $\begin{array}{llll}\text { sediment. Journal of Hydraulic Engineering, 129(2), 128. } & \text { 120-128 }\end{array}$ https://doi.org/10.1061/(ASCE)0733-9429(2003)129:2(120)

Williams, R. D., Rennie, C. D., Brasington, J., Hicks, D. M., \& Vericat, D. (2015). Linking the spatial distribution of bed load transport to morphological change during high-flow events in a shallow braided river. Journal of Geophysical Research: Earth Surface, 120(3), 604-622. https://doi.org/10.1002/2014JF003346

Wolman, M. G. (1954). A method of sampling coarse river- bed material. EOS, Transactions American Geophysical Union, 35(6), 951-956. https://doi.org/10.1029/TR035i006p00951

Wyss, C. R., Rickenmann, D., Fritschi, B., Turowski, J. M., Weitbrecht, V., \& Boes, R. M. (2016). Measuring bed load transport rates by grain-size fraction using the Swiss plate geophone signal at the Erlenbach. Journal of Hydraulic Engineering, 142(5), 04016003. https://doi.org/10.1061/(ASCE)HY.1943-7900.0001090 
Zolezzi, G., Bertoldi, W., \& Tubino, M. (2006). Morphological analysis and prediction of river bifurcations. In G.H. Sambrook Smith, J.L. Best, C.S. Bristow, G.E. Petts (Eds.), Braided rivers: Processes, Deposits, Ecology and Management (pp. 233-256). Oxford, UK: Blackwell Publishing Ltd

\section{Acknowledgements}

This research was supported by funds from the University of Padova (DOR funds). The authors would like to thank: Silvano Pecora, Mauro Del Longo, Monica Branchi and Paolo Leoni from "Servizio Idro-Meteo-Clima" of Arpae Emilia-Romagna for providing hydrological and meteorological data and for their crucial support throughout the whole monitoring activity; Maria Laura Trento and Pietro Brenna for field assistance. The authors thank the associate editor and five reviewers of the journal for their comments and very helpful suggestions. Data supporting figures, relations and elaborations reported in this work can be found in the Supporting Information. 
Table 1. The seven input factors configurations adopted for the bed material load estimation.

\begin{tabular}{lcccc}
\hline & & & \\
\\
\hline
\end{tabular}


Table 2. Bed material flux estimates obtained using seven configurations of the virtual velocity approach. Estimate variability and partial transport contribution are reported. Bold numbers refer to the most complete configurations applicable for the specific calculation, whereas underlined numbers refer to the simplest configurations that could be appropriate to estimate the transport for the specific section and event (see also Figure 11).

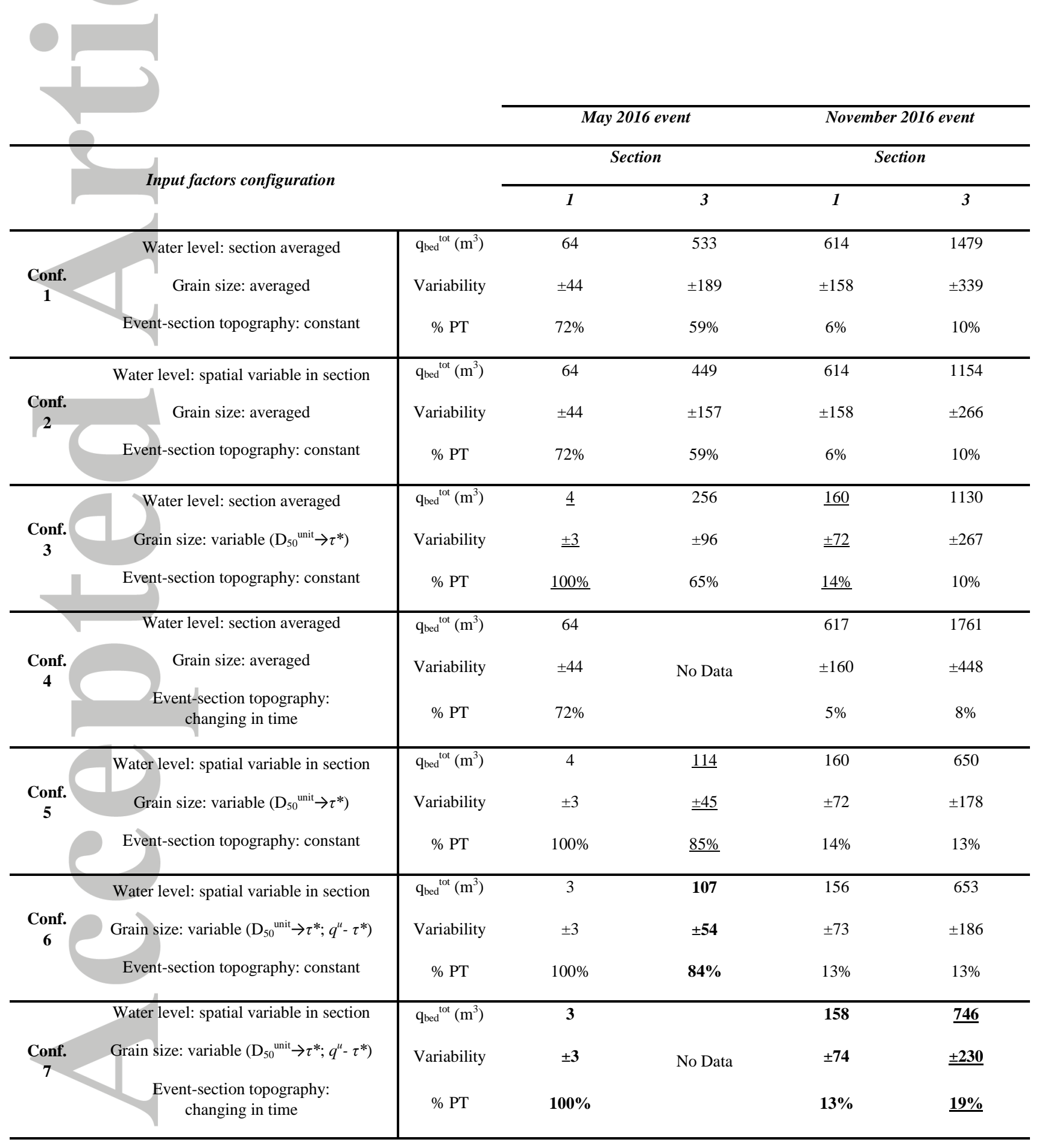



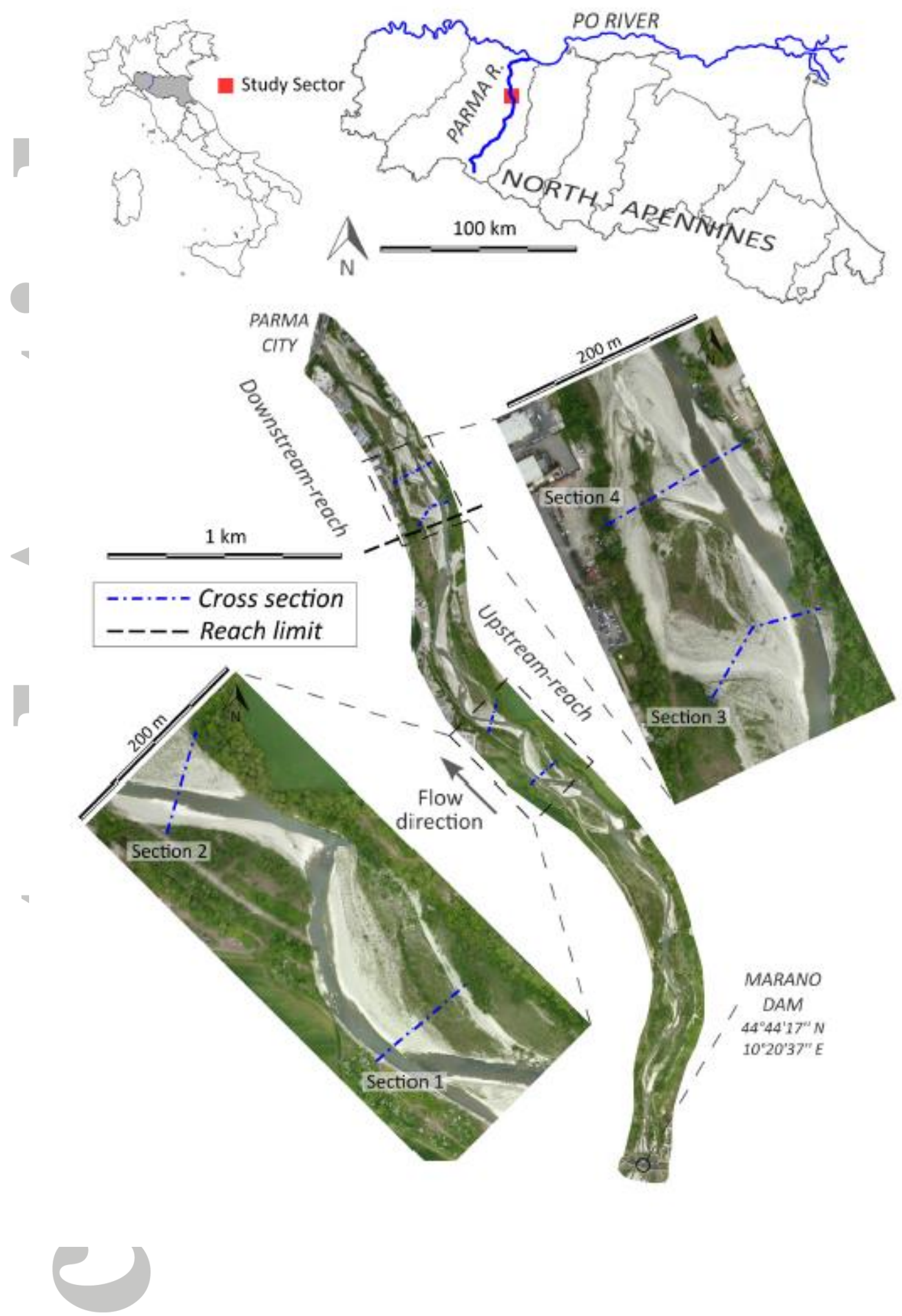

Figure 1. Location of the Parma River and monitored cross-sections positions within the study sector. 


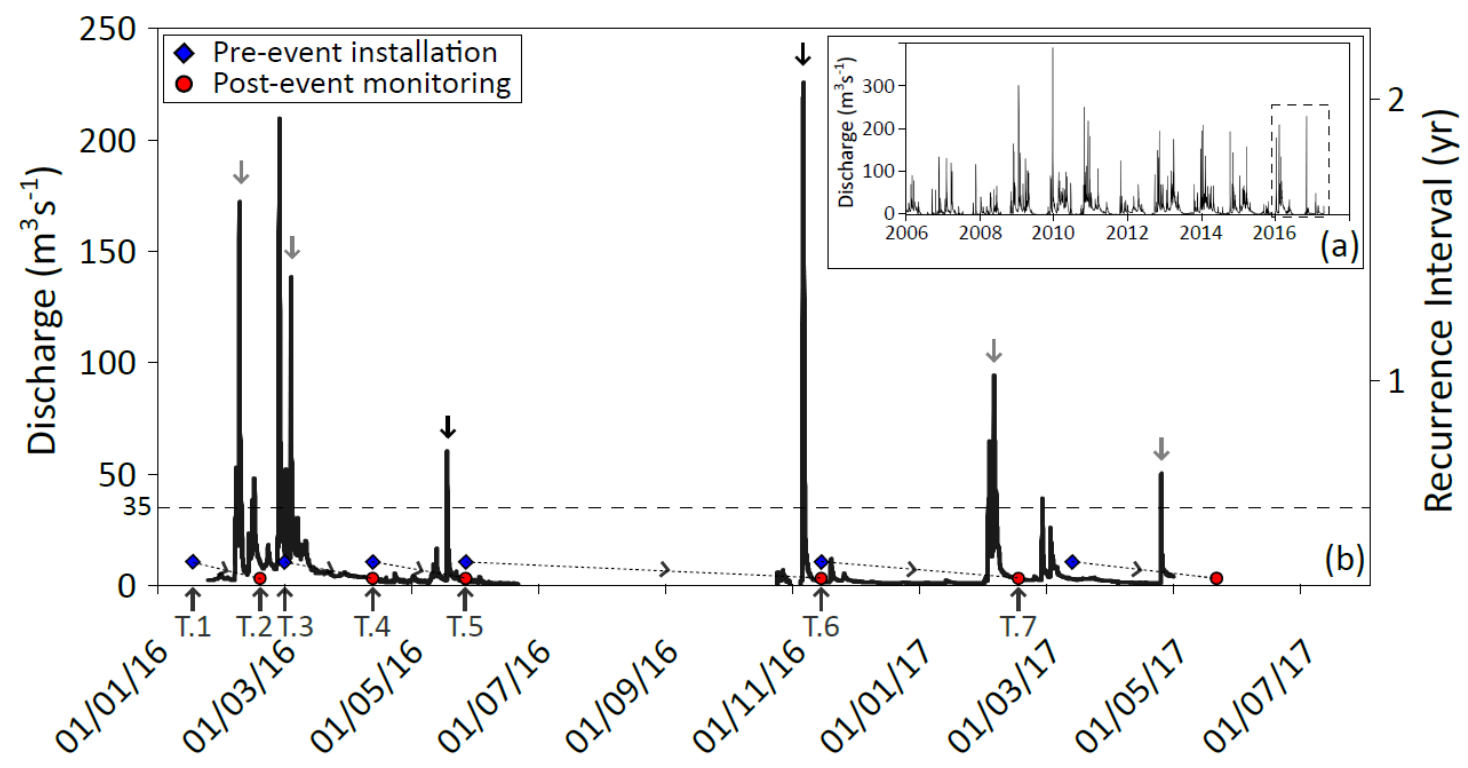

Figure 2. Hydrographs during the last 11 years (a) and during the monitoring period (b). In (b), the vertical arrows point out the six monitored events. The timing of the acquired crosssections topographies, the pre-event installations and the post-event monitoring are plotted in (b).

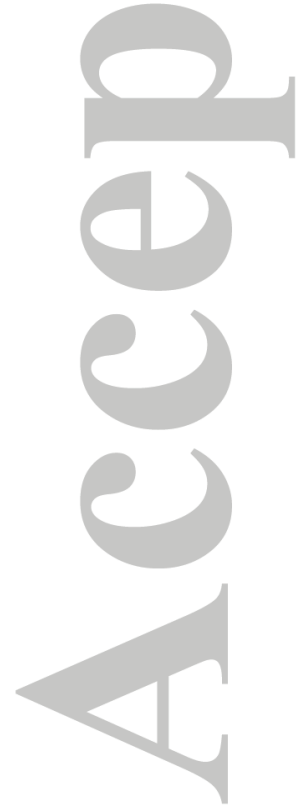




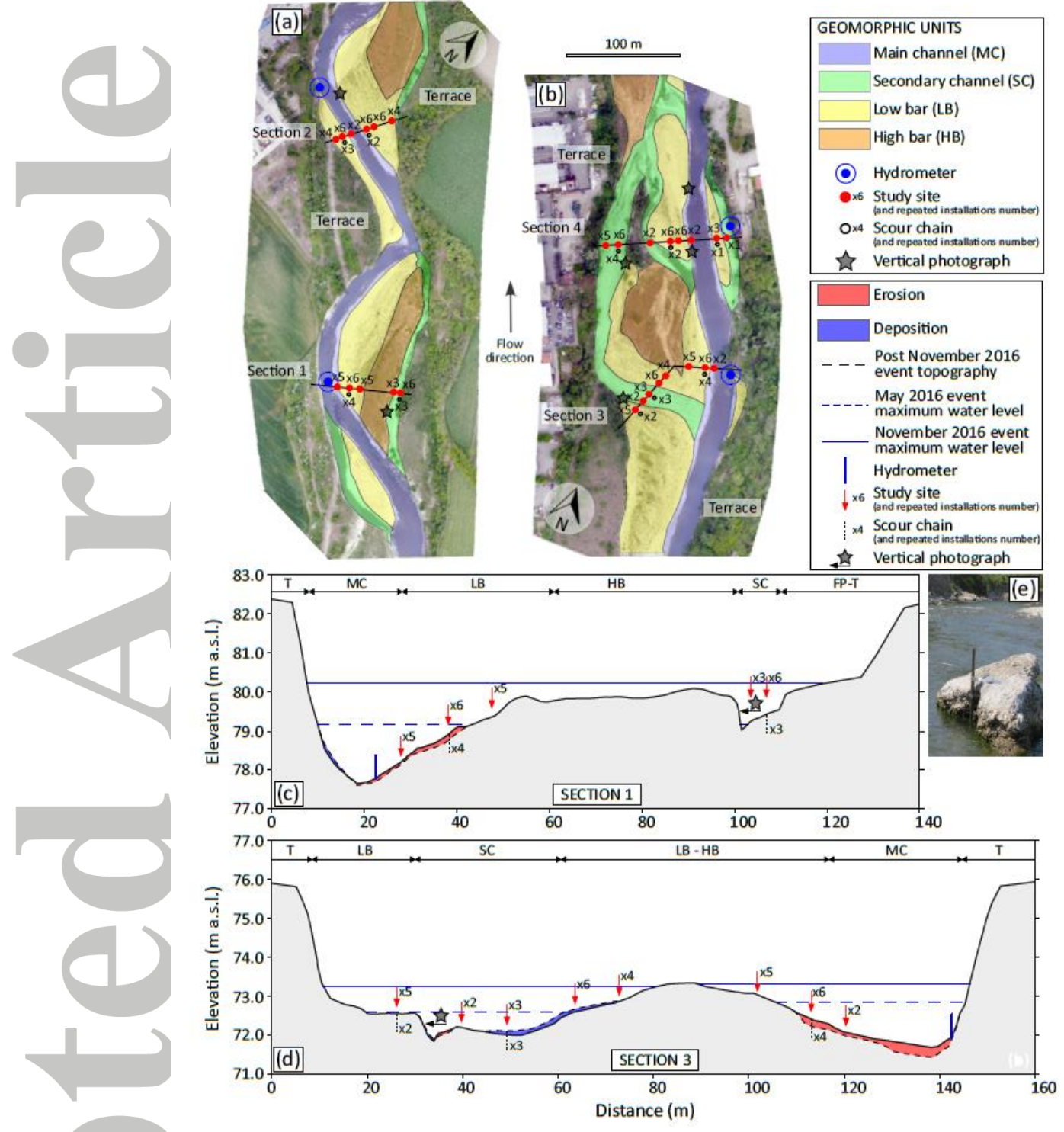

Figure 3. Aerial photographs (April 2016) of the study sections areas and the two crosssections (section 1 (a); section 3 (b)) considered for the transport calculations. Geomorphic units are shown (MC: main channel; SC: secondary channel; LB: low bar; HB: high bar; FP: floodplain; T: terrace). Cross-sections (section 1 (c); section 3 (d)): black continuous lines identify the May-event and the November pre-event topography while dotted lines refer to the post-November 2016 event topography. Hydrometers (installation example is provided (e)), study sites (i.e. painted areas), scour chains and vertical photographs positions are plotted as well. 

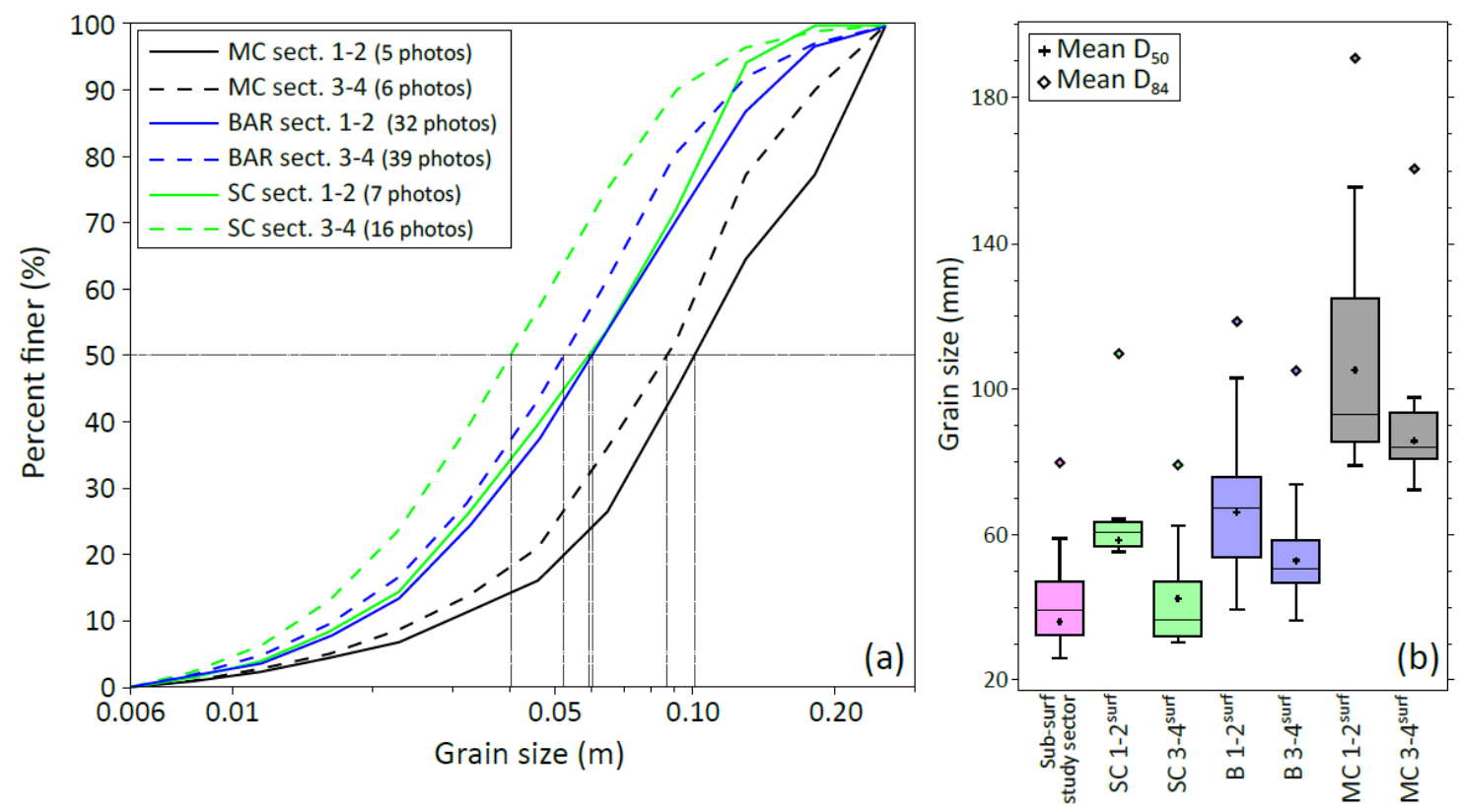

Figure 4. The surface grain size distribution curves truncated at $6 \mathrm{~mm}(\mathbf{a})$ and the study sites $D_{50}$ and $D_{84}$ box plot (b) of the channel surface and subsurface sediments. Surface sediments were divided in six groups according to location and geomorphic unit (MC: main channel; SC: secondary channel; B: bar). In the plot (b), boxes ends represent the $25^{\text {th }}$ and $75^{\text {th }}$ percentiles, whiskers ends are the $10^{\text {th }}$ and $90^{\text {th }}$ percentiles, crosses and lines respectively indicate the mean and the median $D_{50}$ values, diamonds indicates the mean $D_{84}$ values. 


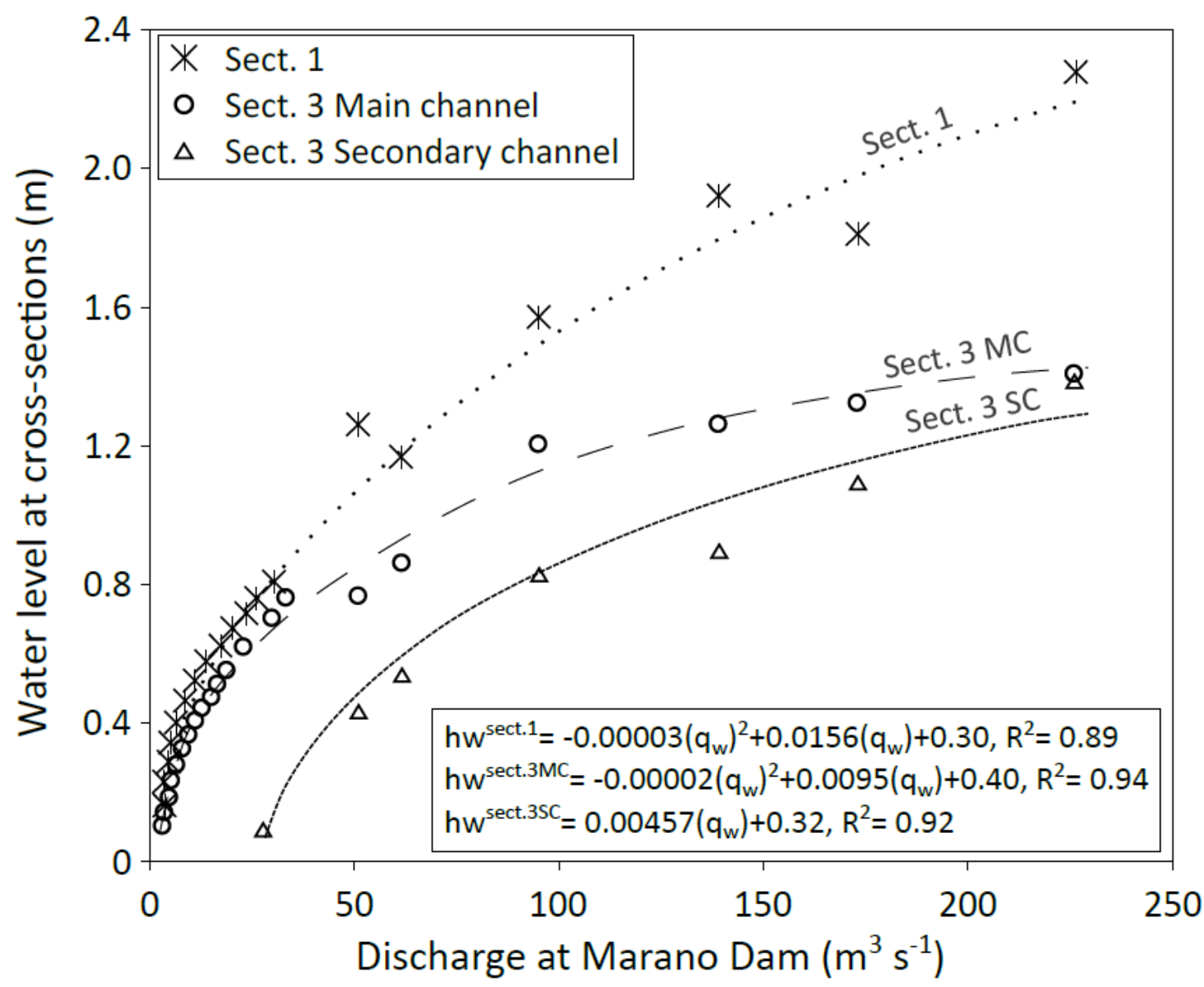

Figure 5. The maximum water level (i.e. water stage at the deepest point of the considered section or section-part. MC: main channel; SC: secondary channel) as a function of discharge. Data are distinct based on location (section 1 and section 3 ). The three final relationships adopted to determine the instantaneous local water stages $\left(\mathrm{h}_{\mathrm{w}}\right)$ from water discharge data $\left(\mathrm{q}_{\mathrm{w}}\right)$ are plotted as well. Trash line elevations have an error of $\pm 0.02 \mathrm{~m}$ due to instrumental accuracy. 


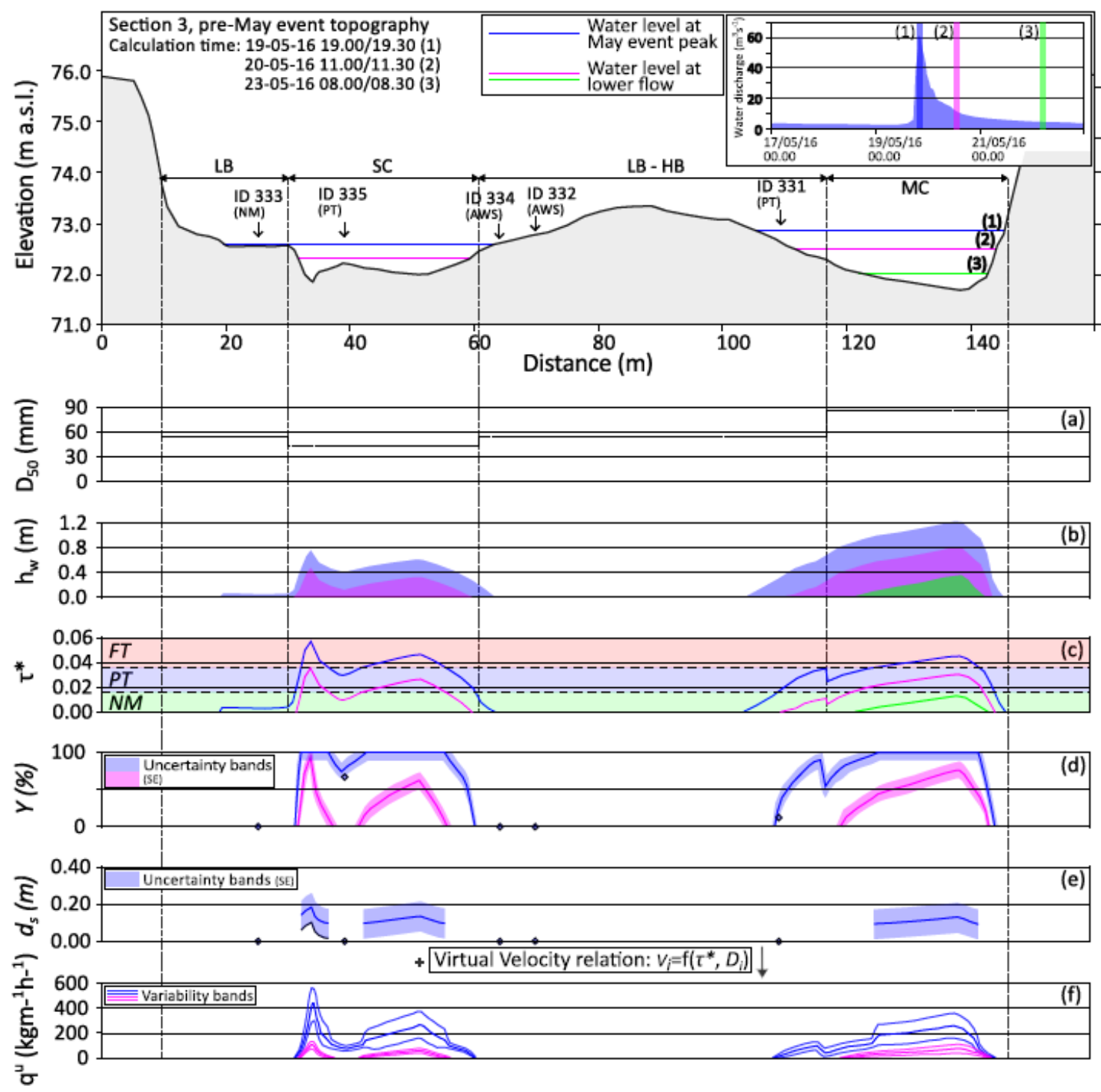

Figure 6. Example of input data (section topography, a, b), instantaneous and local calculation of parameters involved in the estimation $(\mathbf{c}, \mathbf{d}, \mathbf{e}$ ) (uncertainty bands derive from the standard errors reported in Figure 7) and instantaneous-local and section estimated transport (f). Three time intervals of the May event at section 3 are considered. Lines in lower plots refer to values calculated from the derived empirical relations applying configuration 6. Pre-event topography is considered: the five study sites installed before May event are plotted in the section scheme and the punctual field monitored parameters $\left(Y, d_{s}\right)$ are indicated with diamonds. 

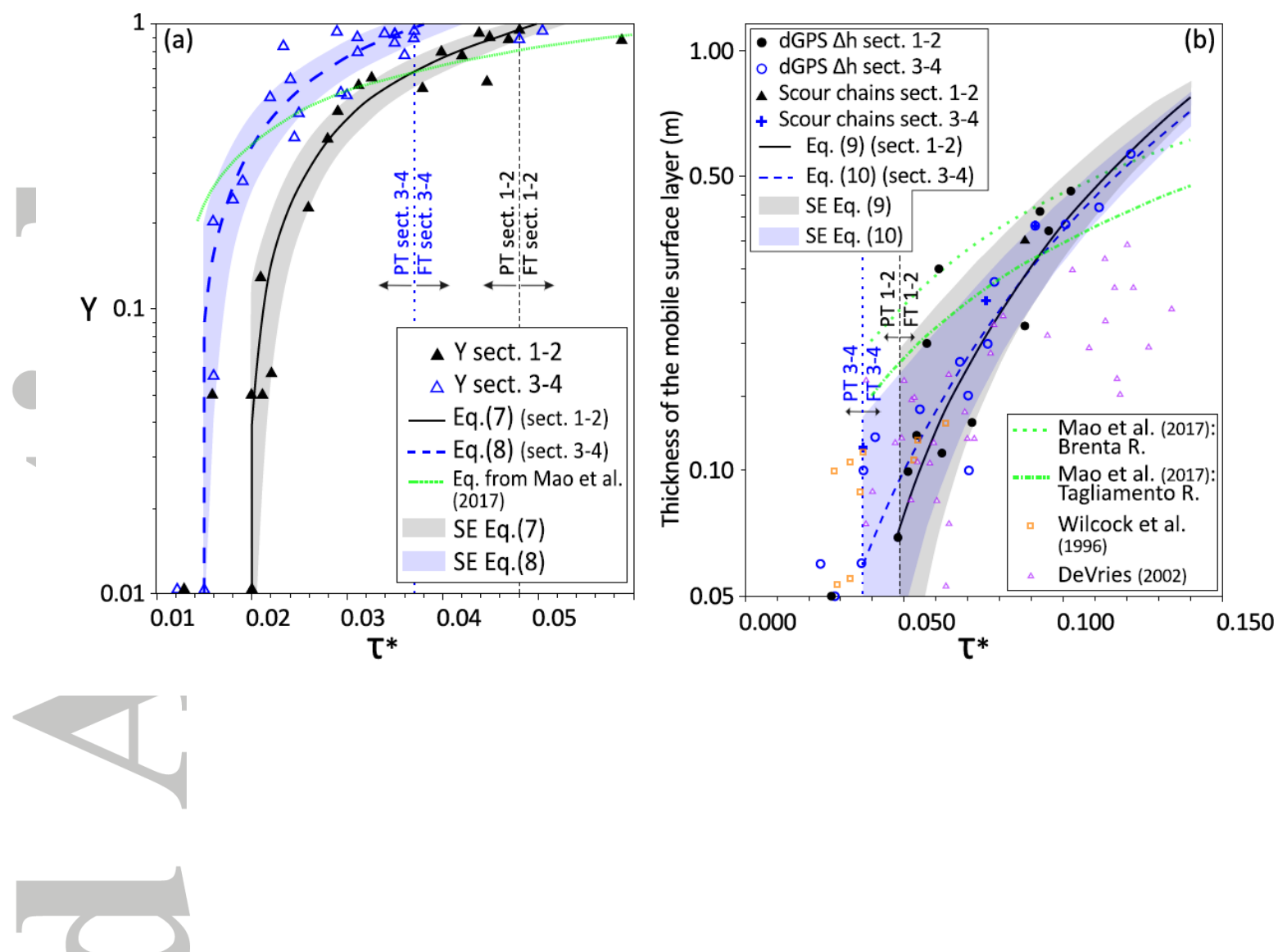

Figure 7. Measured proportion of mobilized streambed (a) and mobile surface layer thickness (b) as a function of $\tau^{*}$. Data are divided on the base of location (sections 1-2 in black and 3-4 in blue) and type of survey. Obtained regression relations are plotted with their uncertainty bands (SE). For comparison, in (a) the relation between proportion of mobilized streambed and $\tau^{*}$ obtained by Mao et al. (2017) considering their whole dataset is plotted as well. In (b) the relations between mobile surface layer thickness and $\tau^{*}$ obtained by Mao et al. (2017) and the data collected by Wilcock et al. (1996) and by DeVries (2002) are plotted as well. 

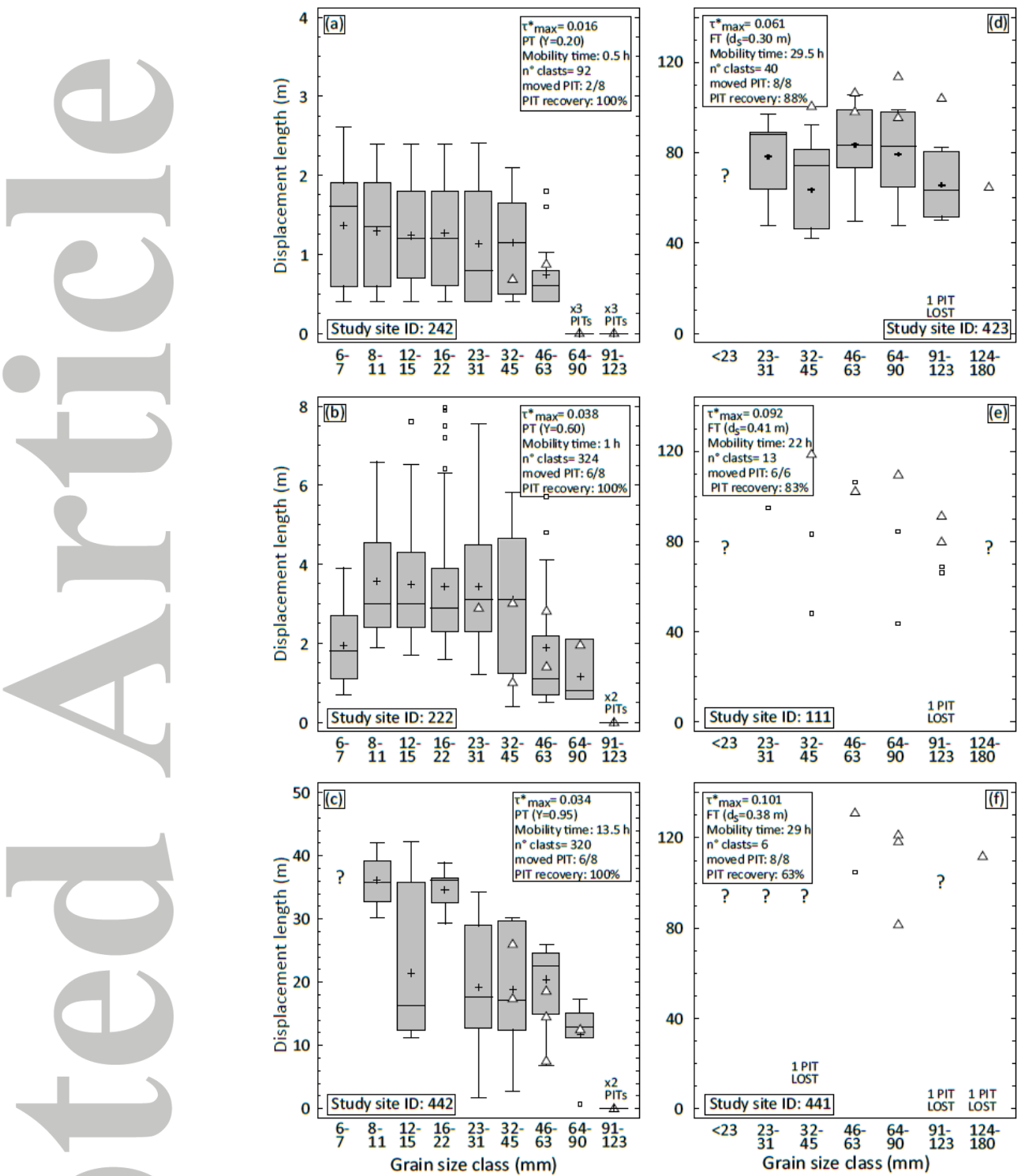

Figure 8. Ranges of tracers displacement lengths. Six study sites characterized by different maximum $\tau^{*}$ and mobility conditions are shown. Data are divided in grain size classes. Boxes and small squares refer to painted clasts while triangles to PITs. Question marks mean that no tracers were found for a specific size class. Knowing the number of PIT tags installed and entrained at each site, it is possible to report the number of PITs moved but not recovered (i.e. PIT lost). 

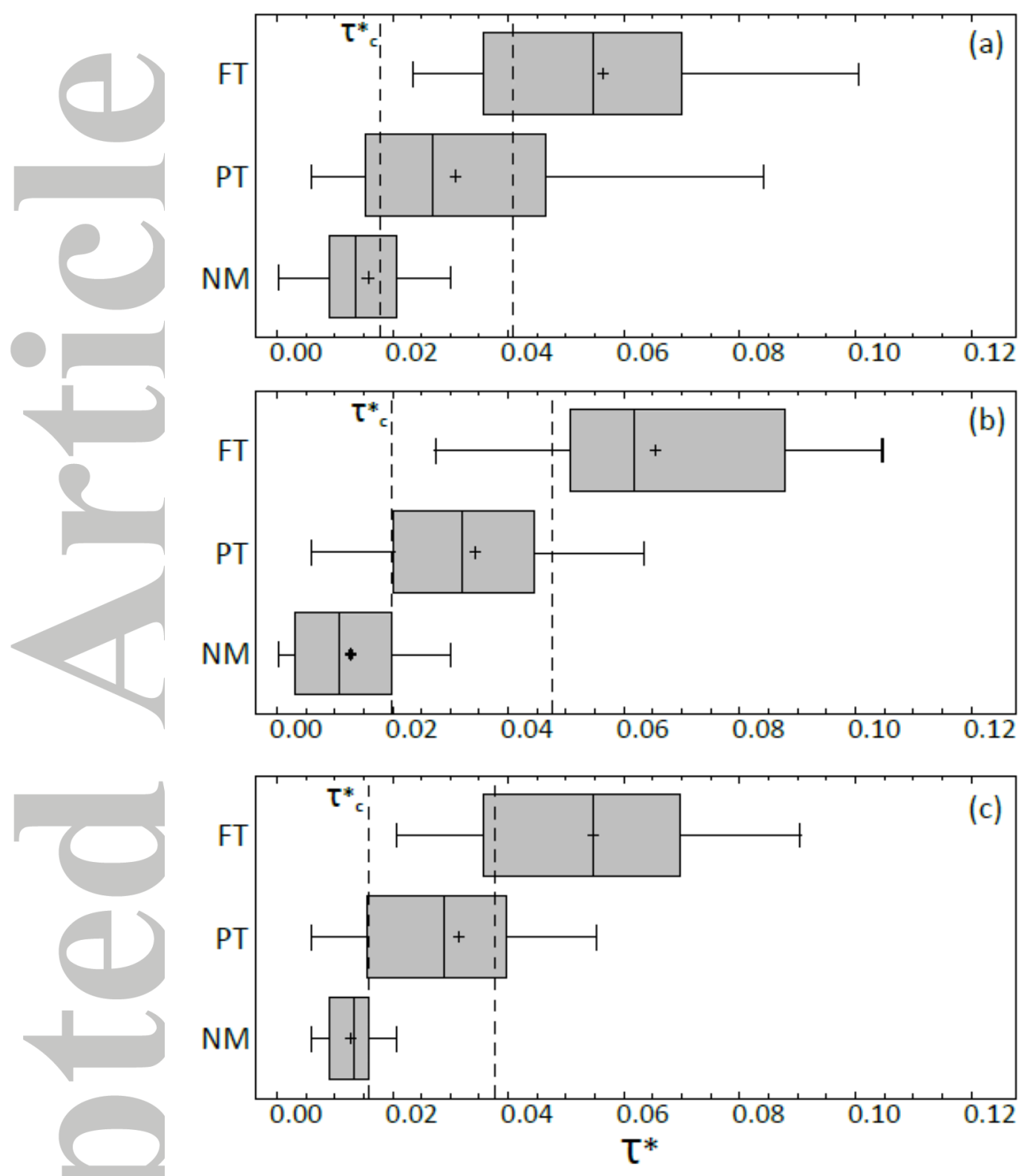

Figure 9. Ranges of the maximum $\tau^{*}$ acting over the painted areas inducing different sediment mobility conditions (NM: no motion; PT: partial transport; FT: full transport). Boxes ends represent the $25^{\text {th }}$ and $75^{\text {th }}$ percentiles while whiskers ends are the $10^{\text {th }}$ and $90^{\text {th }}$ percentiles. Crosses indicate the mean values and lines indicate the median values. Plot (a) refers to the whole dataset, plot (b) to sections 1-2 and plot (c) to sections 3-4. The thresholds between different mobility conditions (dashed lines) vary considering the three analyzed datasets. Critical shear stress $\left(\tau^{*}\right)$ refers to the passage from NM to PT condition. 

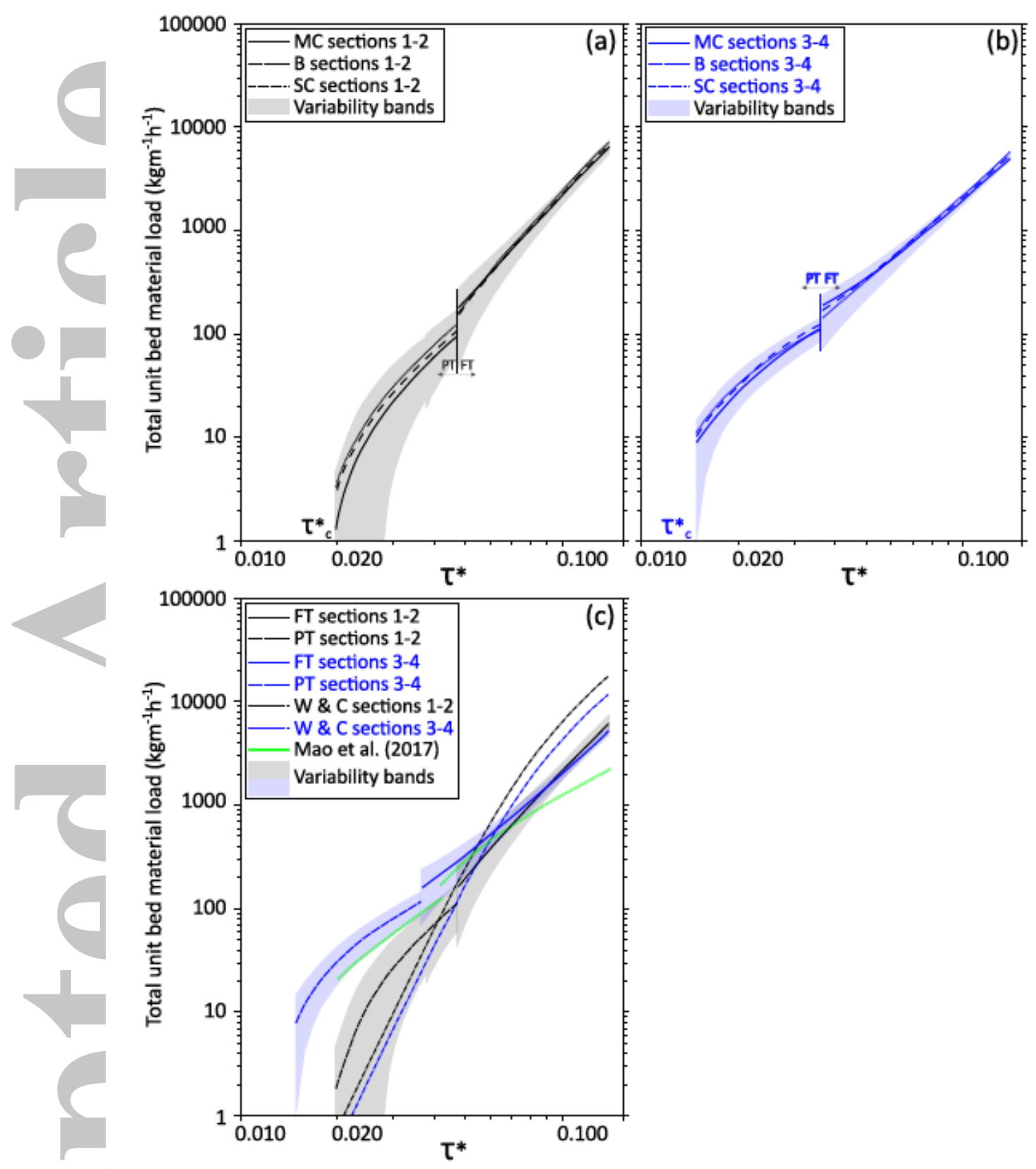

Figure 10. Section and morphological-unit specific sediment transport rating-curves obtained from virtual velocity approach application as a function of the $\tau^{*}$. (a) refers to sections 1-2 and (b) refers to sections 3-4, and each line-type refers to a specific geomorphic unit (MC: main channel; SC: secondary channel; B: bar). Each curve has its variability band but for graphical reasons they are shown together for sections 1-2 and 3-4 curves. In (c) are reported the two mean $\tau^{*}-q^{u}$ relations for both sites (derived considering one average grain size distribution curve for sections 1-2 and for sections 3-4). Rating curves resulting from Wilcock and Crowe (2003) formula (W\&C) (i.e. considering a specific mean grain size distribution curve for sections 1-2 and for sections 3-4) and rating curve obtained by Mao et al. (2017) are plotted in (c). 


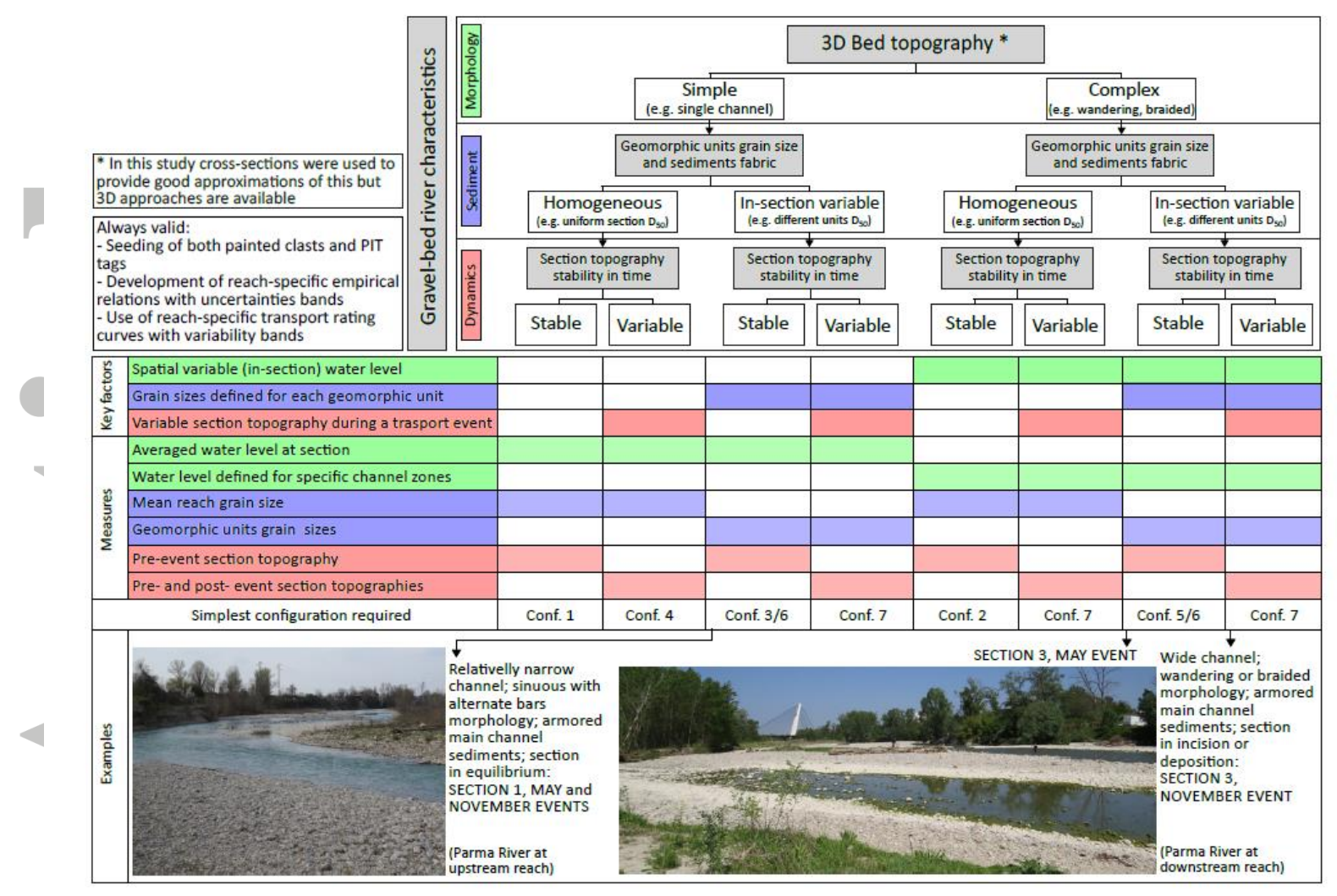

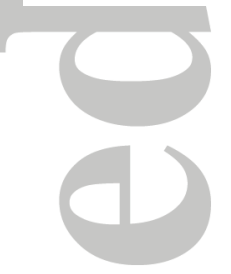

Figure 11. Decision tree for using the virtual velocity approach in different gravel-bed river contexts. Reach morphology and sediment characteristics usually can be assumed constant for the entire study-period, while section topography dynamics depends by both the reach equilibrium conditions and the intensity of the specific competent event. Most influencing application factors, required measures and simplest adequate configurations are reported for specific cases. Examples from this work are shown as well. 